\title{
The Effect of Blended Learning on Language Proficiency of an EFL Class: An Empirical Study
}

Jamile Sulam Tango Rojas

West Virginia University, jt0084@mix.wvu.edu

Follow this and additional works at: https://researchrepository.wvu.edu/etd

Part of the First and Second Language Acquisition Commons, and the Online and Distance Education Commons

\section{Recommended Citation}

Tango Rojas, Jamile Sulam, "The Effect of Blended Learning on Language Proficiency of an EFL Class: An Empirical Study" (2020). Graduate Theses, Dissertations, and Problem Reports. 7609.

https://researchrepository.wvu.edu/etd/7609

This Thesis is protected by copyright and/or related rights. It has been brought to you by the The Research Repository @ WVU with permission from the rights-holder(s). You are free to use this Thesis in any way that is permitted by the copyright and related rights legislation that applies to your use. For other uses you must obtain permission from the rights-holder(s) directly, unless additional rights are indicated by a Creative Commons license in the record and/ or on the work itself. This Thesis has been accepted for inclusion in WVU Graduate Theses, Dissertations, and Problem Reports collection by an authorized administrator of The Research Repository @ WVU. For more information, please contact researchrepository@mail.wvu.edu. 
The Effect of Blended Learning on Language Proficiency of an EFL Class: An Empirical Study

Jamile Sulam Tango Rojas

Thesis submitted to the Eberly College of Arts and Sciences

at West Virginia University

in partial fulfillment of the requirements for the degree of

Masters in TESOL

Nicole Tracy-Ventura, Ph.D., Chair

Heiko ter Haseborg, Ph.D., Co-Chair

Tania de Miguel Magro, Ph.D.

Department of World Languages, Literatures, and Linguistics

Morgantown, West Virginia

2020

Keywords: blended learning, online lessons, face-to-face lessons, language proficiency, language skills, English as a foreign language, asynchronous lessons

Copyright 2020 Jamile Tango 


\section{Abstract \\ The Effect of Blended Learning on Language Proficiency of an EFL Class: An Empirical Study}

\section{Jamile Sulam Tango Rojas}

The combination of online learning and face-to-face lessons have become a relevant learning model in English Language Teaching in the last years. The goal of this research study was to investigate the integration of such a blended learning approach in an EFL class in Bolivia. The study was conducted at a binational language institution, and it focused on the effect of blended learning on the students' overall language proficiency and each language skill individually. Data was collected via a proficiency pre-test at the beginning of the experiment, two quizzes during the module, and a final exam, all of them to assess the students' learning. This study also investigated the students and teacher's attitudes towards the blended learning approach, for which individual interviews were conducted. The participants were 31 Bolivian students of parallel intermediate level classes of English. They were divided into a comparison group $(\mathrm{n}=18)$ and a treatment group $(\mathrm{n}=13)$. The results showed that, overall, the comparison group performed better than the treatment group. However, the treatment group performed equally or better than the comparison group in some language skills. Regarding the students' and teacher's attitudes towards the online lessons, they were positive regarding the interactivity and the feedback, but negative regarding the opportunities of communication in the online lessons. 


\section{Dedication}

This thesis is dedicated to my parents, Graciela Rojas and José A. Tango, since wherever I have reached my career today, it is because of their love and endless support in all my decisions; and to my Access students for being the inspiration to write it. 


\section{Acknowledgements}

I would like to express my deepest gratitude to the Fulbright program for making this degree and study take place.

I would like to recognize the invaluable assistance of my thesis tutors, Dr. Nicole TracyVentura and Dr. Heiko ter Haseborg. Their trust, encouragement, and great advice was wholeheartedly appreciated during the process of the research.

I would like to pay my special regards to the language institution where the study was completed, more specifically, to the Executive Director Silvia Solares, to the Academic Director Raquel Torrico, to the teacher Melvin Urizar, whose assistance was a milestone in the completion of this investigation.

I would also like to thank my parents, family, and friends for having being there for me when I needed it the most.

Finally, an enormous thank you to Abi for arriving upon the scene of this journey when I least expected it and making it somehow even more special than it already was. 
Table of Contents

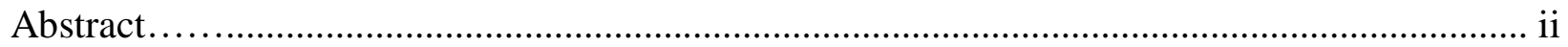

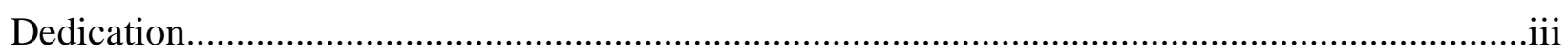

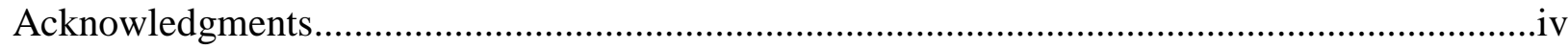

Table of Contents...........................................................................................................

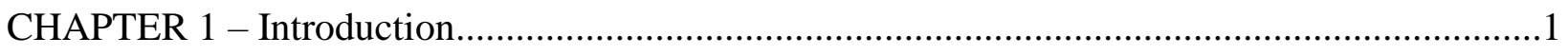

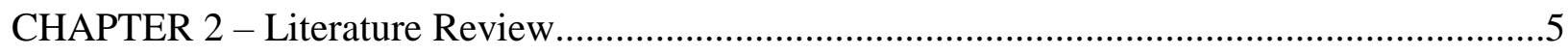

Students' Perceptions, Insights, and Attitudes .......................................................

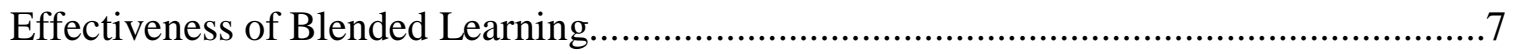

Blended Learning Models............................................................................

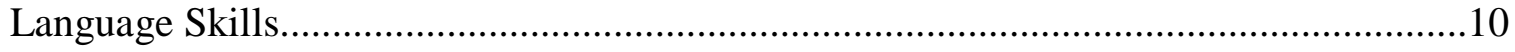

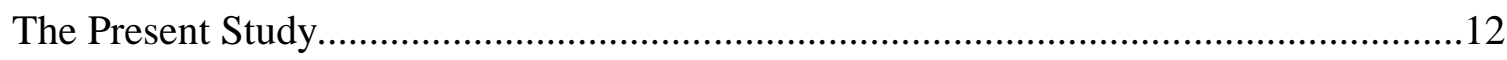

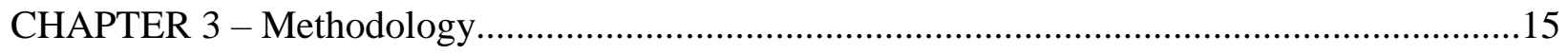

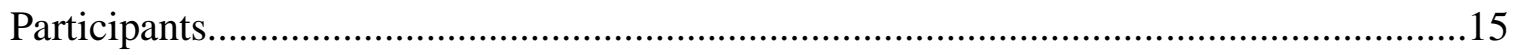

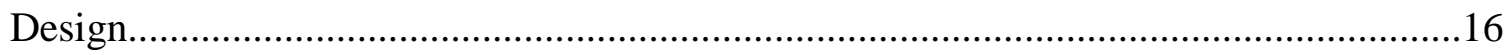

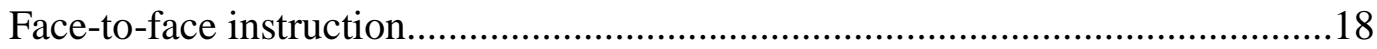

Blended lesson instruction.................................................................... 18

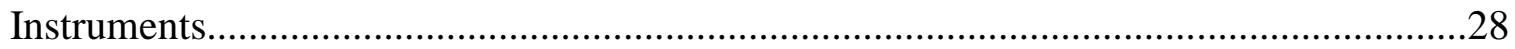

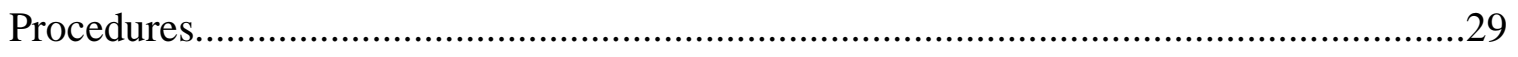

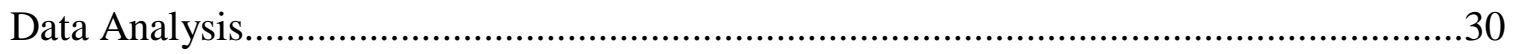

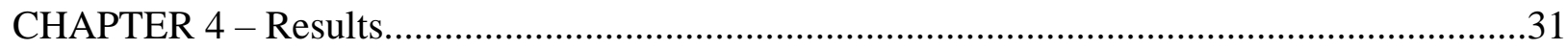

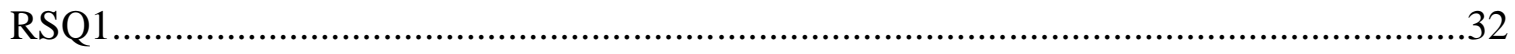

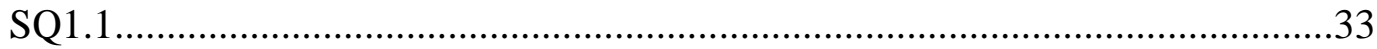




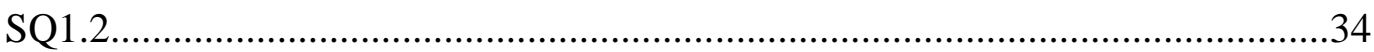

SQ1.3

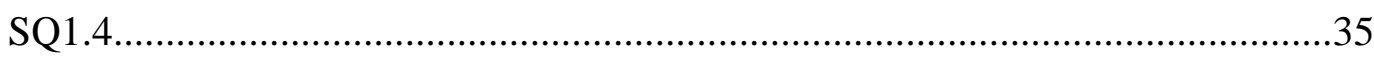

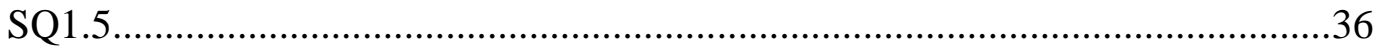

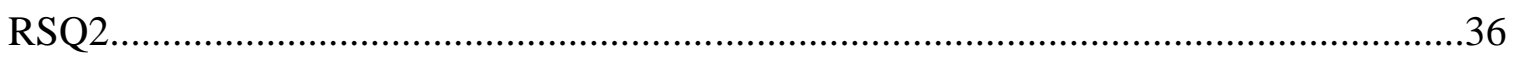

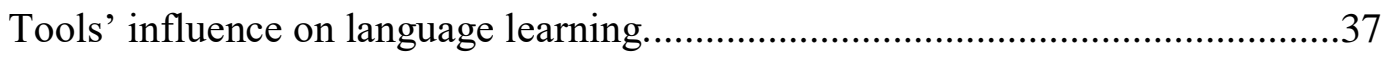

Online course difficulty and not helpful elements........................................40

Communication skills effect...................................................................43

Reflection and self-feedback on their own skills...........................................44

Teacher's attitudes towards blended learning...............................................46

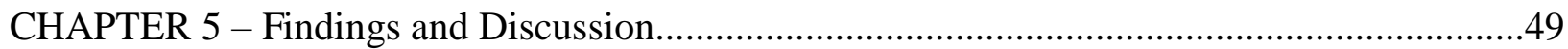

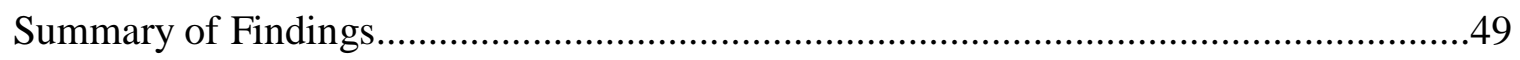

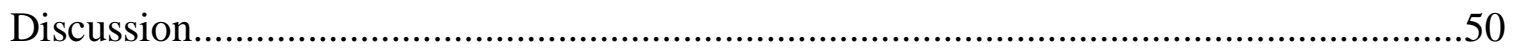

Limitations and Implications for Future Research..............................................53

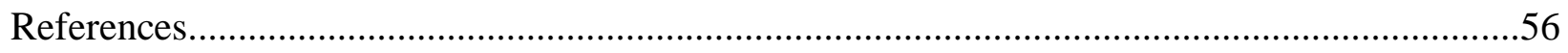

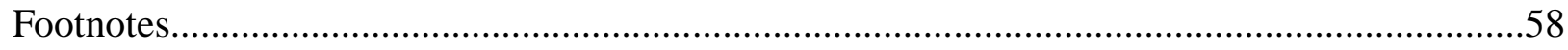

Table 1: Mean and Standard Deviation of Pre-Test Scores...................................................31

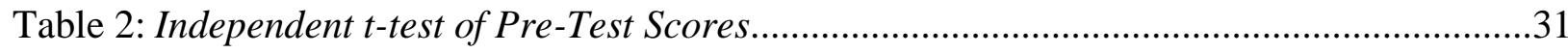

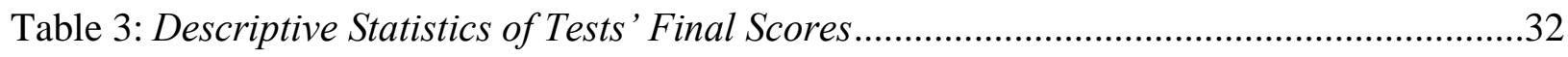

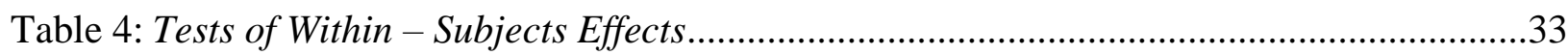

Table 5: Mean and Standard Deviation of All Skills Final Exam 's Scores.................................33

Table 6: Independent t test of Grammar \& Vocabulary Final Exam 's Scores............................34

Table 7: Independent t test of Reading Final Exam 's Scores...................................................34 
Table 8: Independent t test of Listening Final Exam 's Scores...................................................35

Table 9: Independent t test of Writing Final Exam 's Scores...................................................35

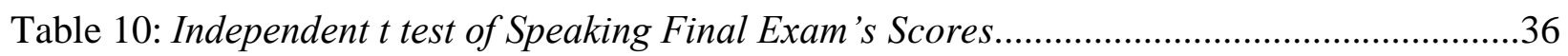

Figure 1: Comparison and Treatment Groups Class Schedule ..............................................17

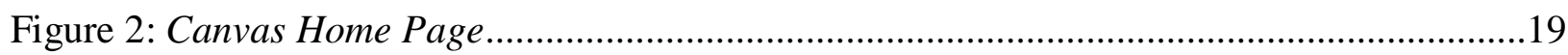

Figure 3: Canvas Modules Distribution Page ....................................................................19

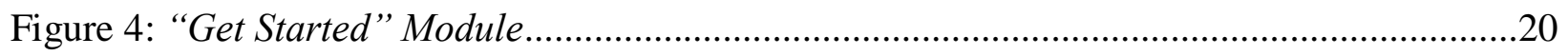

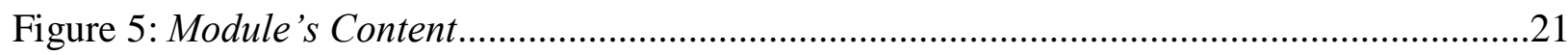

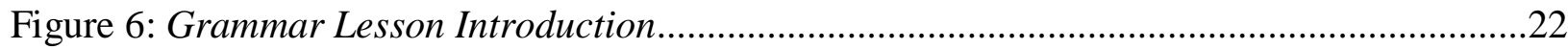

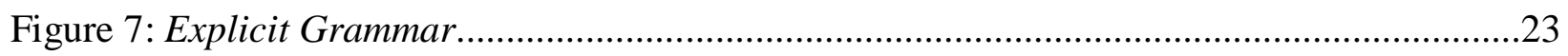

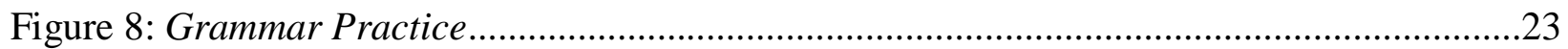

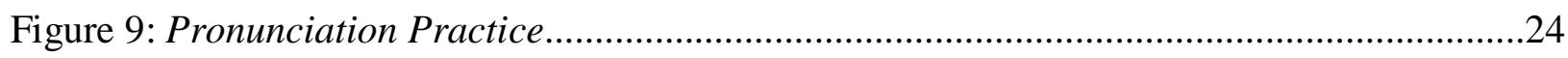

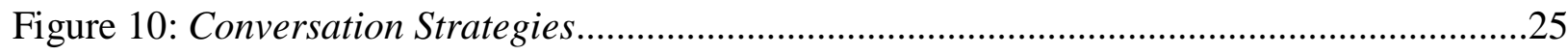

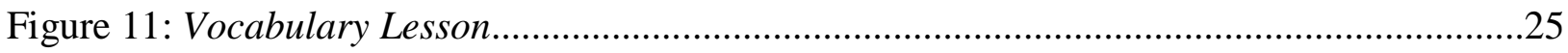

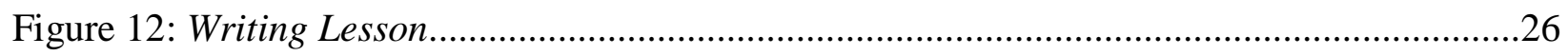

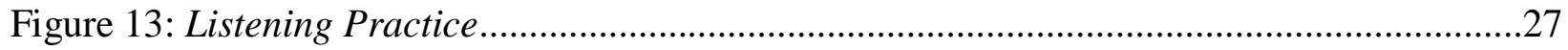

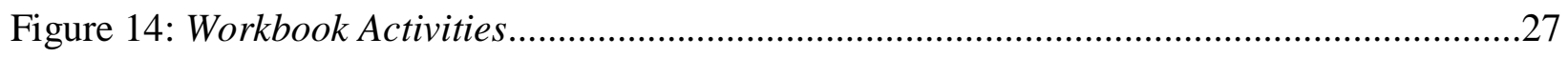

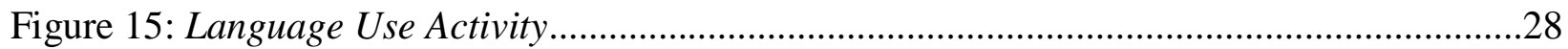

APPENDIX A: Final Exam Units 3-4 (Pre-test)............................................................59

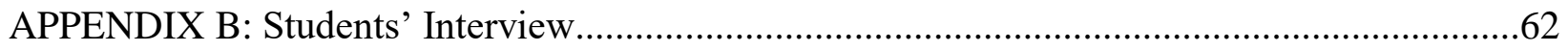

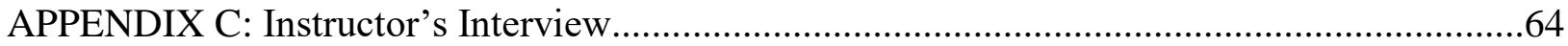

APPENDIX D: Post-Experiment Students’ Interview Spanish Translation..............................65 


\section{CHAPTER 1}

\section{Introduction}

As demonstrated over the last decades, technology has played an important and integral role in people's daily lives, and when combined with the internet, it has become an essential part in most humans' activities, such as communication, shopping, transportation, education and most importantly for this thesis, teaching and learning English as a second or foreign language (ESL/EFL). The integration of technology in ESL/EFL classrooms is advancing every day, and it has brought with it plenty of benefits and advantages not only for students but also for teachers such as phone learning apps, online learning platforms and sites, corpus-based online learner dictionaries, assessment online tools, and plenty of resources which help English teachers deal with different classroom challenges and develop successful instructional materials for their lessons.

The present study focuses on one application of technology in the classroom: blended learning. Many studies describe and argue about the different definitions of blended learning and its integration effect on a language institution. According to Oliver and Trigwell (2005), blended learning has three different meanings in the field of education. The first one considers blended learning as an integration of the regular face-to-face kind of learning with online Learning Management Systems (LMS) such as Canvas, Schoology or Google classroom and web tools to promote learners' interaction outside the classroom. The second one defines blended learning only as the integration of different web tools, so lessons are only given in an e-learning environment rather than in a face-to-face class. Finally, the third definition refers to the combination of methodologies and/or approaches used in a class, such as a combination of 
communicative language teaching with a total physical response approach, according to Claypole (2010, as cited by Sharma, 2010).

Blended learning started to be used around twenty years ago in the corporate/business domain so employees could have the necessary availability to be able to work and study at the same time (Driscoll, 2002). This new form of technology primarily benefited employers because they did not need to give employees time off work to attend class, thus avoiding a loss of productivity. Instead of having lessons in a classroom, workers were exposed to digital materials such as books, videos or the web in general (Driscoll, 2002). Even though all of this was mainly to keep employees in the workplace, nowadays, the numerous goals and uses of blended learning have transcended much further than that.

As an English teacher in a developing country, I am aware of the various improvements and advancements we need in EFL teaching, particularly in the area of integrating technology into the classroom. Learning a language is considered a dynamic and interactive process because learners need to be active and participate in a class to practice the language skills they are learning; however, in order to do that, a person who wants to study English needs to have enough time to dedicate to going to class every day until they achieve their desired language proficiency. People from all ages sometimes have little or no time to dedicate to language learning, and even less time to commute to a language school every day due to schoolwork, university schedules, or inconvenient office hours. Hence, blended learning can be considered a way to improve and innovate lessons by giving learners a chance to learn both in a face-to-face environment and at their own pace, with asynchronous lessons and practice allowing them to have their lessons part of the time from home. 
The definition of blended learning adopted in the current study is a combination of faceto-face and online teaching comprising the use of synchronous and asynchronous electronic tools (Sharma, 2010). Even though, according to Driscoll (2002), it can be assumed that blended learning has more advantages than disadvantages thanks to all the benefits that entails and how positively described it is, some issues have been found in different studies as it will be described in the literature review. According to VanDerLinden (2014), blended learning also requires the combination of different roles, such as the role of technology, the role of faculty, and the role of institutions. Thus, it is not only about teachers and students anymore, but also about the result of everyone's collaborative work within an institution. This means that there are several aspects that should be considered and may affect the success of a blended classroom. For example, it depends on the context and situation of where it is applied (Ashby, 2015); if it is used to respond to learners' needs and designed based on their skills and access to technology, it might result in the same or a better impact than face-to-face lessons on learners' language proficiency.

This thesis comprises five chapters. The first chapter, this introduction, outlines the rationale and significance of the study, and explains how the thesis is structured. The literature review is developed in the second chapter and presents the research on blended learning and the research questions investigated in the present study. The third chapter portrays the methodology used for this study, describing the participants, design, instruments, procedures, and a brief summary of the data analysis. The results and the answers to the research questions are presented in the fourth chapter. Finally, Chapter Five describes and discusses the findings, limitations, and implications of the research. 
The following review of literature aims to synthesize primary and secondary research in order to provide an overview of definitions, models, approaches, and conditions for the integration of blended learning which has informed the current study. 


\section{CHAPTER 2}

\section{Literature Review}

In this literature review, I will focus on the most relevant points and/or themes of the study. The students' attitudes, insights, and perceptions in different studies will be taken into consideration since they are important factors in assessing the effectiveness of blended learning. Furthermore, different models of blended learning integration in some studies will be presented in order to examine their procedure. Finally, since the focus will be on analyzing the effectiveness of blended learning on language proficiency, I will analyze the methods that some studies used and how well they helped to improve language proficiency.

\section{Students' Perceptions, Insights, and Attitudes}

Students' motivation and acceptance of being part of the integration of a blended learning course is important for this study since its effectiveness also depends on how students will experience and perceive it. Tayşı and Başaran (2018) investigated the perceptions of EFL students and instructors from a state university in Turkey toward the implementation of an online learning management system called MyELT which was utilized for the implementation of a blended learning course. MyELT allowed students to work at home for language boosting through extra practice exercises about vocabulary and pronunciation after having 20 hours of face-to-face instruction. The students participated in the project for two semesters. The overall findings showed that students had positive perceptions about the practicality of the MyELT system. The students' average grade scores and the descriptive statistics for their perceptions of the usefulness of the platform on their language skills showed that there was also a positive outcome in the students' listening, reading and grammar skills, but according the students' interviews, they had more difficulties with the skills of writing and vocabulary when these 
lessons were given in an online format; however, the study's correlational statistics showed that there was not a significant relationship between the students' perceptions of the language management system and their grade scores. A negative attitude was also shown due to the limited access some of them had to the internet and the technical problems they experienced with the program which affected their preference for having online quizzes and exams.

Akbarov, Gönen, and Aydoğan (2018) aimed to examine students’ attitudes and perceptions towards blended learning and surveyed 162 university students from all language competence levels. In the case of this study, students were exposed to quantitative data collection through a questionnaire about their attitudes towards blended learning and its different components such as the combination of traditional and online classrooms, digital material in the classroom, the way of submitting assignments, etc. The results of this study showed that overall students preferred blended learning lessons rather than a face-to-face regular classroom. However, they also liked to take English exams in paper-and-pencil form, rather than in digital form. As for submitting English assignments online or in person, their opinions were divided. They also similarly trusted analog teaching/learning materials more than the ones that are digital; nonetheless, statistics showed that there was not a significant difference between the number of students who preferred one over the other. Students had a moderately positive attitude toward infographics and a paperless (digital) classroom within an EFL environment.

Martín de Lama (2013) also carried out a study which partly focused on students' perceptions regarding the deficiencies they found during the integration of the blended learning course. Qualitative data collected from interviews, such as the students and teachers' perceptions and opinions about the tools that were available and the use of them were considered for data collection. These insights were also backed up by the quantitative data gathered from tests that 
were given throughout the whole academic year to study their progress and improvement. In this study, students' opinions were negative about some of the tools that did not allow prompt feedback from instructors due to the fact that some of those tools were misused by the students, which gave a space for the researchers' suggestion of including other web tools that could be used for instant communication such as familiar social networks or Web 2.0. tools that could increase the opportunities of real interaction for feedback in English.

In sum, the three studies showed positive student perceptions toward blended learning, with some negative opinions about the accessibility to mobile and computer devices or the lack of technological competence towards some of the learning management systems that were used. Furthermore, one relevant constraint that the students highlighted is the delayed response they received from the instructors in the online forums, and how much more difficult it was to ask their instructor about their doubts in comparison with their regular classroom lessons. These are important facts that need to be considered in future research.

\section{Effectiveness of Blended Learning}

One of the research questions investigated in this thesis is whether a blended approach is effective in comparison with a traditional (face-to-face) approach. Gill (2009) focuses her study on comparing a group with face-to-face lessons and another group with blended learning lessons to see which of the approaches is more effective and which techniques are better than others while implementing them. According to this research design, by combining face-to-face and online lessons, activities, and assessment that respond to the learners' needs and measure their performance, attitudes, and motivation towards this kind of approach, the data from both groups can be compared and evaluated with the goal of making improvements and changes until the learners' needs are met. By following this design, the research results showed that blended 
learning activities were considered to be more relevant for learners than the ones that were faceto-face because they were more active and in a virtual learning environment. Moreover, some of those online activities had a better outcome and effect on students than others because they involved more participation, collaborative work between learners, games, threaded discussions, etc., which, according to the post-semester questionnaire that the participants answered, was interesting and helpful for them to prepare for the exams, and improve their overall language skills more.

These results echo Rao (2006) who states that for a blended learning course to be effective, it has to be customized regarding the attitudes, beliefs, and needs of the learners. Motivation is an important factor; therefore, the students need to be aware of the importance and benefits of the course they are taking. Moreover, the content has to be designed in order to be relevant, current and utilizable. Finally, Rao states, "Blended learning is changing in its implementation mechanism and covers a number of interesting and imaginative ways in which course design, learning activity styles, and the information environment are changing" (Rao, 2006, p.35), all of which leads towards an effective blended learning process.

Not all research has focused on the effectiveness of blended learning. Harrington (2010) focuses on the implications and potential problems it may have or cause regarding other areas such as forced individualism which, according to her, is more common in writing lessons. The author explains that most American writing courses, especially academic writing, are individualized because of elements such as voice, peer review, critical thinking, and textual ownership, which causes problems for English learners since in their native cultures they are used to have more collaborative work and harmonization instead of this individuality. As argued by Harrington, in a blended class, forced individualism is even more intense because students 
have less time in face-to-face lessons, complete tasks alone while sitting in front of a computer isolated from their classmates, and therefore, have fewer opportunities for peer review or collaborative work. She also states that this process may raise the affective filter as a result of the constant requirement to participate from discussions and ideas sharing, making learners feel anxious, intimidated and pressured; however, the affective filter would raise in the same way or even more with the same activity in a face-to-face class. Nevertheless, it is still a concern to be considered while designing blended classes.

\section{Blended Learning Models}

The different platforms, web tools, strategies, and models the research studies used are also relevant in order to examine how useful they were, how well they performed, and their overall benefits and shortcomings. The study of Bañados (2006) proposed a model to be adapted to large classes of students in Chile. The research was conducted with a sample of 39 students who had to be part of one of four program modules that lasted an academic semester. This program merged the students' self-directed learning through ICT (Information and Communication Technology) with a traditional face-to-face lesson with a teacher that was also the instructor who monitored their work with the ICT and guided a weekly discussion with English native speakers. At the end of the program, students finish with 100 hours of interactive language learning tasks concentrated on their needs, personal motivation, future plans and relevant information that could be useful for a person to communicate in an English-speaking country. The improvement of the pilot group's language skills was examined through a comparison between an initial diagnostic test they took at the beginning of the program and a final end-of-term test. This result was as significantly positive as their approval with the whole course, which was evaluated with a satisfaction survey at the end of the module. 
Alonso, López, Manrique, and Viñes (2005) conducted a similar study; however, their model focuses more on content structure, information-processing psychology, and social constructivism rather than in the technological part itself. For this model of blended learning to be successful, the author mentions some essential components such as an instructor who manages digital communication tools in the classroom and explains specific learning subjects to the group; learners who raise questions and interact with each other stimulating group learning, support, and a help forum for subjects related to learning management.

Models can vary and should be adapted according to the context in which they are planned to be applied. As Bañados (2006) stated, it is important to analyze this context considering the learners' needs, the educational contents, the environment where the model will take place, the faculty involved, and the available resources in order to achieve the goal of having learners be engaged by the blended learning program so they get can learn and understand content that they did not before. There are unlimited options since plenty of aspects have to be considered, such as the ones mentioned above, but once they are accordingly combined and adapted, a blended approach can be an efficient model (Bañados, 2006).

\section{Language Skills}

According to this study's research questions, what is needed to be examined is whether blended learning has either positive or negative effects on students' language competence. However, it is also possible that the effects may differ depending on the skill. For instance, in the study of Gleason (2013), one instructor gave the face-to-face lessons and another the hybrid lessons to 28 and 22 Spanish students, respectively. The model for the first group of 28 students comprised four 50-minute traditional lessons per week and the model for the second group consisted of only two 50-minute traditional lessons and one 25-minute online lesson in an online 
communication platform called Adobe Connect. It is worth noting that whereas the blended course provided students 125 minutes of class per week, the traditional course provided students with 200 minutes giving less time of class to the blended learning group assuming students would have more extra time to work at home asynchronously according to their own pace rather than attending face-to-face lessons. In the analysis of the results related to language competence, it was found that students had more opportunities to produce their oral skills by thinking in the target language in the face-to-face lessons. Instead in the online lessons, there were only a few who participated actively and voluntarily in the different activities provided while the others were mostly just listeners answering only what they were asked to do. Feedback was also important in the online lessons since students had to give an oral presentation through the ICT and the teacher assessed that and paraphrased what the student said with the necessary corrections and comments through the chatbox.

Zhang and Zhu (2018) conducted another study that focused on identifying the outcomes related to learning skills through the comparison of blended learning and face-to-face learning too but taking into account if the number of years of instruction, gender and discipline of the students affected the result. They worked with a big sample of 5376 first year and second year undergraduate students who were part of ESL courses in Beijing, China. Focusing on communication skills, students were able to interact with the instructor and their classmates in the target language through forums and chats. A comparative analysis of the results of a proficiency exam taken at the beginning and end of the academic year showed that students in the blended learning course obtained better academic achievement than students in the other group. In the case of this study, the author describes that due to the flexibility and convenience of blended learning; it enhanced student motivation and satisfaction with the learning environment 
since they were able to interact with each other in the discussion forums, sharing opportunities they had and evidencing a sense of online interactive community for the students, which encouraged them to interact more and use the target language in their oral production when in the face-to-face lessons.

One purpose of these studies was to improve oral communication skills through blended learning because it is hypothesized that students may not have the same opportunities to interact in an online environment as they would have in the classroom. Therefore, further research is needed focusing on the effect of blended learning on each of the skills that are normally assessed and evaluated in English language classes. To help address this gap, the current study investigates the effectiveness of blended learning at an English program in Sucre, Bolivia in order to examine if there were differences in students' language proficiency depending on whether they participated in blended learning or traditional face-to-face classes.

\section{The present study}

In general, this literature review suggests that the findings from empirical studies were mostly positive after the implementation of a blended learning approach, if the blended learning course was designed for a specific group of learners who were in a context where it was necessary to integrate such an approach. Nevertheless, there were also some limitations that interfered with the whole process.

There is general acceptance that blended learning can be beneficial, not only from the students' perspective but also the teachers'. However, as Tayşı and Başaran (2018) concluded, a lot of planning and analysis is needed before implementation since overlooking some details may cause big problems affecting students' learning process, performance, attitude, and motivation towards this approach. 
About the models, each study adapted similar models of blended learning and there are countless more out there. However, this again goes back to the importance of choosing the model that is the best fit for the institution, faculty, and students, so it can be appropriately adapted with the least possible constraints. Additionally, the models we saw in the empirical studies just described did not focus only on one skill specifically, they only considered final grades, result of all the skills combined, but not each skill separately. This is an important implication of the findings since it is relevant to know how blended learning affects each of the skills in order to see if the approach is more helpful or not in each of them.

Therefore, what this research proposes is a combination of some of these studies. The study examines the effect of blended learning on language skills, such as writing, reading, listening, writing, grammar, and vocabulary considering the students' needs of real-world communication. Another different procedure from all the studies reviewed is the length of each module in the implemented model. The present study is done in a module no longer than 17 weekdays where students are evaluated three times during the whole module. All of this is in order to have more quantitative data to measure language proficiency and obtain more specific results that can be compared. The study also utilizes a similar procedure to the study of Zhang and Zhu (2018) making a comparison between two classes of the same language competence level which have the same syllabus, and with the difference that one of them received blended learning lessons and the other face-to-face lessons.

Therefore, the research questions guiding this study are the following:

- Research question 1: Are there significant differences in overall proficiency between students in blended learning and students in face-to-face learning approaches? 
- Sub-question 1.1: Are there significant differences in grammar and vocabulary between students in blended learning and students in face-to-face learning approaches?

- Sub-question 1.2: Are there significant differences in reading skills between students in blended learning and students in face-to-face learning approaches?

- Sub-question 1.3: Are there significant differences in listening skills between students in blended learning and students in face-to-face learning approaches?

- Sub-question 1.4: Are there significant differences in writing skills between students in blended learning and students in face-to-face learning approaches?

- Sub-question 1.5: Are there significant differences in speaking skills between students in blended learning and students in face-to-face learning approaches?

- Research question 2: What are the students and teacher's attitudes towards the blended learning approach in comparison to their regular face-to-face lessons? 


\section{CHAPTER 3}

\section{Methodology}

\section{Participants}

The participants of this study were Spanish native speakers from Sucre, Bolivia, and as mentioned before, the study was done in an EFL context. They were young adult students who belong to a 39-month-long English program at a binational center, a non-profit institution whose main activity is teaching EFL to children, teenagers, and adults. Students who enroll in this program will have a $\mathrm{C} 1$ level of English once they finish it; thus, their overall goal is to be proficient enough in the language for their personal or professional purposes.

The students who took part in this study were adults between 18 and 35 years old in a pre-intermediate / B1 level class. They were selected based on convenience, that is, in order to have two parallel classes that were studying the same content and had the same instructor. For this to happen, both classes had to be at different times. One of the classes was the comparison group which had regular face-to-face lessons as they usually do at the institution, with no change at all. The other class was the treatment group which had blended lessons, that is, half of their classes were face to face and the other half online. To ensure that the participants had the same proficiency level at the beginning of the study, the results of their final exam from the previous module was collected, compared and analyzed.

The comparison group had eighteen students and the treatment group had thirteen students. All the participants volunteered to be part of the study. Hence, aspects such as gender, race or ethnicity were not considered as a variable since they were not relevant for the purposes of the study. All participants signed an informed consent document before the study began. 
In the case of the administration and instruction part, one instructor taught both groups, using the same syllabus and content, but on different schedules. The instructor worked on the methodology and models to be used in the experiment with the researcher. The administrative staff such as the Executive and Academic Directors were also involved and helped throughout the study. Finally, another instructor conducted the interviews with the students and the instructor at the end of the module.

\section{Design}

The syllabus design that was employed for this research is based on the syllabus of the English program at the binational center. As part of their syllabus, they use the "Top Notch 3" textbook from Pearson editorial, and the data for this study come from their classes focusing on units 5 and 6 from the textbook.

The comparison group had their regular face-to-face instruction for 1.5 hours a day, from Monday to Friday, following the regular class syllabus and lessons of the English program. In contrast, the treatment group had face-to-face instruction for 1.5 hours a day on Mondays, Wednesdays, and Fridays and asynchronous online instruction for 1.5 hours a day on Tuesdays and Thursdays. As shown in Figure 1, the module duration was seventeen days, where on the eighth day, both groups took a quiz about unit 5 , on the $16^{\text {th }}$ day, a quiz about unit 6 , and on the $17^{\text {th }}$ day a final exam about both units. For the treatment group, students followed the content of the syllabus with the same lesson order in a learning platform called CANVAS which is a cloud based LMS (Learning Management System) that is designed to be used on computers or mobile devices. With the utilization of this LMS, the treatment group studied the same content as the comparison group but with different activities such as forum discussions, voice discussions, and listening activities that involved authentic audio and video materials. The LMS allowed students 
to interact with each other, and at the same time to interact with and receive feedback from the instructor.

Figure 1

Comparison and Treatment Groups Class Schedule

\begin{tabular}{|c|c|c|c|}
\hline Day & Duration & COMPARISON GROUP (F2F Lessons) & TREATMENT GROUP (Blended Learning) \\
\hline & & \multicolumn{2}{|c|}{ Final Exam, Units 3 and 4 (Previous course) } \\
\hline 1 & 1.5 hours & Unit 5: Natural Disasters. Introduction & Unit 5: Natural Disasters. Introduction. \\
\hline 2 & 1.5 hours & Lesson 1: SWBAT convey a message. & Online lesson. Lesson 1: SWBAT convey a \\
\hline 3 & 1.5 hours & Lesson 2: SWBAT report news. & Lesson 2: SWBAT report news. \\
\hline 4 & 1.5 hours & Lesson 3: SWBAT describe natural disasters. & $\begin{array}{l}\text { Online lesson. Lesson 3: SWBAT describe } \\
\text { natural disasters. }\end{array}$ \\
\hline 5 & 1.5 hours & Lesson 4: SWBAT prepare for an emergency. & Lesson 4: SWBAT prepare for an emergency. \\
\hline 6 & 1.5 hours & Writing Booster: Organizing detail statements. & Writing Booster: Organizing detail statements. \\
\hline 7 & 1.5 hours & Unit Review + Grammar Booster & Online lesson. Unit Review + Grammar Booster. \\
\hline 8 & & \multicolumn{2}{|c|}{ Quiz \# 1, Unit 5} \\
\hline 9 & 1.5 hours & Unit 6: Life Plans. Introduction to the unit. & $\begin{array}{l}\text { Online lesson. Life Plans. Introduction to the } \\
\text { unit. }\end{array}$ \\
\hline 10 & 1.5 hours & $\begin{array}{l}\text { Lesson 1: SWBAT Explain a change in life and } \\
\text { work plans. }\end{array}$ & $\begin{array}{l}\text { Lesson 1: SWBAT Explain a change in life and } \\
\text { work plans. }\end{array}$ \\
\hline 11 & 1.5 hours & $\begin{array}{l}\text { Lesson 2: SWBAT express regrets about past } \\
\text { actions. }\end{array}$ & $\begin{array}{l}\text { Online lesson. Lesson 2: SWBAT express regrets } \\
\text { about past actions. }\end{array}$ \\
\hline 12 & 1.5 hours & $\begin{array}{l}\text { Lesson 3: SWBAT discuss skills, abilities, and } \\
\text { qualifications. }\end{array}$ & $\begin{array}{l}\text { Lesson 3: SWBAT discuss skills, abilities, and } \\
\text { qualifications. }\end{array}$ \\
\hline 13 & 1.5 hours & $\begin{array}{l}\text { Lesson 4: SWBAT discuss factors that promote } \\
\text { success. }\end{array}$ & $\begin{array}{l}\text { Online lesson. Lesson } 4 \text { : SWBAT discuss factors } \\
\text { that promote success. }\end{array}$ \\
\hline 14 & 1.5 hours & Unit Review + Grammar Booster & Unit Review + Grammar Booster. \\
\hline 15 & 1.5 hours & Writing booster: Dividing an essay into topics & $\begin{array}{l}\text { Online lesson. Writing booster: Dividing an } \\
\text { essay into topics. }\end{array}$ \\
\hline 16 & & \multicolumn{2}{|c|}{ Quiz \# 2, Unit 6} \\
\hline 17 & & \multicolumn{2}{|c|}{ Final Exam } \\
\hline 18 & & \multicolumn{2}{|c|}{ Students and teacher's attitudes interview } \\
\hline
\end{tabular}

At the end of the module, a different instructor at the institution was in charge of conducting the semi-structured interviews with the treatment group and the instructor. These interviews (see Appendix B and C) were used to collect data about their attitudes, insights, and perceptions of the blended learning program they experienced.

The present study has a quantitative and qualitative experimental design, for which the independent variable is the instruction type that students received, and the dependent variables are the students' scores representing their overall language level and for each skill: grammarvocabulary, reading, listening, writing, and speaking. 


\section{Face-to-face instruction.}

The regular face-to-face lessons at this language institution are part of a module of seventeen days. In each module, the content covered from the textbook is two units. In the Top Notch textbook, every unit has an introduction section to the unit: four lessons that include grammar, vocabulary, reading, listening, pronunciation, and speaking; a unit final review section; a grammar booster section; a writing booster section; and a workbook with review exercises. In a regular 1.5-hour class, one of the lessons from the textbookand in the workbook has to be covered (see Figure 1).

The materials used by the teacher were mostly the textbook and the workbook. In the classroom, they had a projector and a computer where they could project the digital version of the textbook and have students complete exercises on the board. The teacher mostly used a deductive approach where each lesson started with a warmp-up mainly focused on authentic communication that introduced the topic of the lesson. Then, it continued with a structure of presentation, practice, and production. Although the book has extra material, such as videos, games, extra activities, etc., it was not possible to implement them in the face-to-face lessons since teachers are required to complete all the exercises of the book and workbook in class.

\section{Blended lesson instruction.}

The online lessons were designed in Canvas, an online learning platform that can be used from individual classrooms to large universities, and from blended learning to fully online learning. This LMS is known for being user-friendly and for allowing instructors and studens to easily connect both in and out of the classroom. It includes basic functionalities such as managing enrollments, sharing documents and media, submitting assignments, working collaboratively, assigning grades, etc. 
As shown in Figure 2, Canvas has a user-friendly interface with a dashboard page that has a quick access to the assignments, modules, announcements, grades, and other convenient information that was useful for the online lessons used in this study. Students also conveniently received notification alerts via email, text message, and via the Canvas app if they were working on their cellphones.

Figure 2

Canvas Home Page

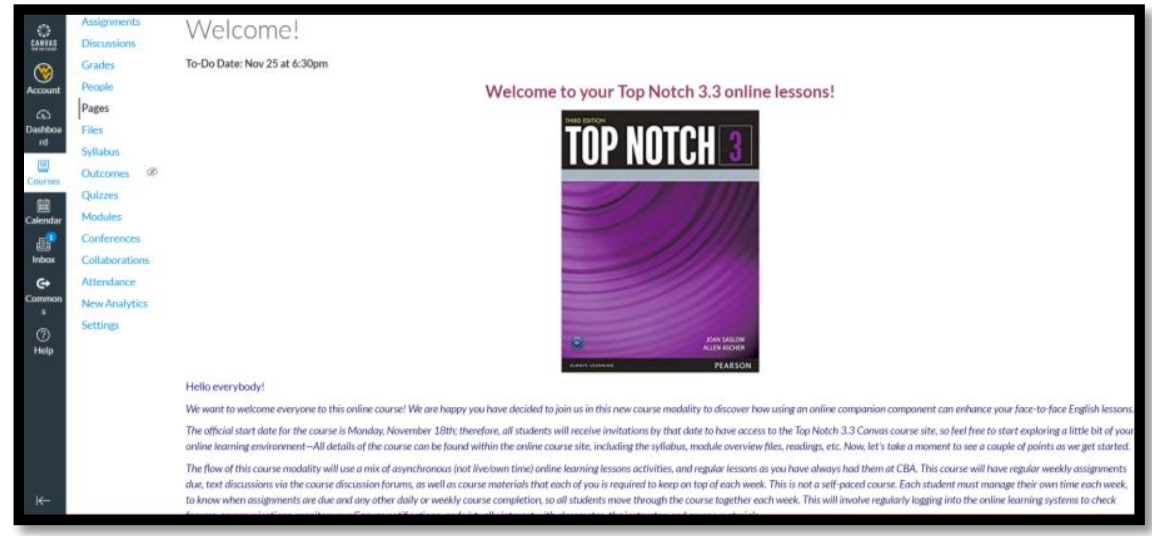

With the purpose of following the same lesson plan as a parallel class, in the online course, each module represented a lesson. The modules page was for students to see all the lessons and activites that were available, as illustrated in Figure 3. To complete each module, they had the prerequisite of first completing the one before; otherwise, the LMS did not allow them to continue with the next one.

Figure 3

Canvas Modules Distribution Page

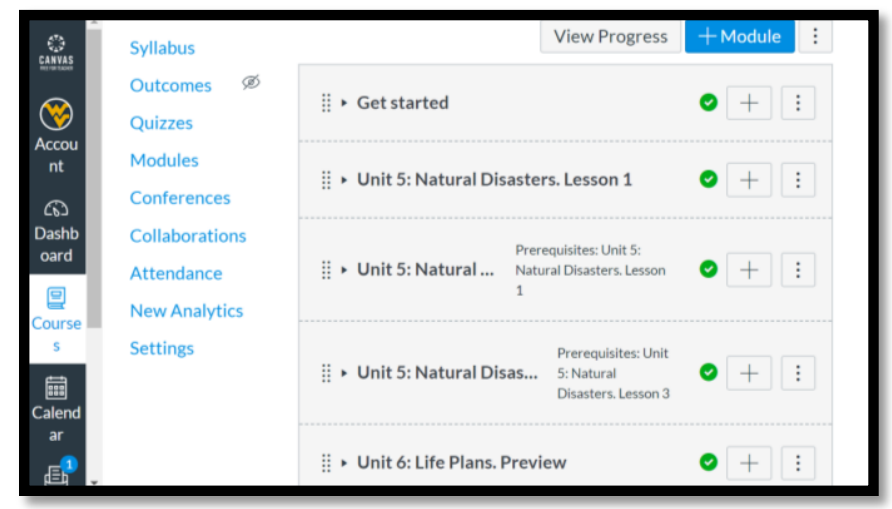


The "Get started" module was important in order to have them get acquainted with the platform. It was a guide that was available for them at any time where they could find a short orientation about the platform, information about where and how to ask for technical support and content help, the course syllabus, etc, as shown in Figure 4. It also had warm-up practice so they could introduce themselves through a discussion forum so they could have a first experience of the how to work in the platform.

Figure 4

"Get Started" Module

\begin{tabular}{|c|c|c|c|c|c|}
\hline & & - Get started & $\odot$ & + & $\vdots$ \\
\hline CAMELS & Modules & $\begin{array}{l}\text { Welcome! } \\
\text { Nov 25,2019 }\end{array}$ & & $\odot$ & $\vdots$ \\
\hline Accou & Collaborations & :1: Canvas User Orientation & & $\odot$ & $\vdots$ \\
\hline$C D$ & & :: Technical support & & $\odot$ & $\vdots$ \\
\hline $\begin{array}{c}\text { Dashb } \\
\text { oard }\end{array}$ & Settings & (1) Content Support Discussion & & $\odot$ & $\vdots$ \\
\hline $\begin{array}{l}\text { Course } \\
\text { s }\end{array}$ & & $\begin{array}{l}\text { :1: Course Syllabus } \\
\text { Nov } 25,2019\end{array}$ & & ○ & $\vdots$ \\
\hline $\begin{array}{l}\text { 細 } \\
\text { Calend }\end{array}$ & & $\begin{array}{l}\text { :1: Participants' numbers } \\
\text { Nov } 25,2019\end{array}$ & & $\odot$ & $\vdots$ \\
\hline 匠 $^{1}$ & & $\begin{array}{l}\text { Introduce yourself } \\
\text { Nov 22,2019 | Opts }\end{array}$ & & $\odot$ & $\vdots$ \\
\hline
\end{tabular}

As mentioned before, each module represented a lesson. As presented in Figure 5, each lesson always began with a review activity of the previous lesson, an introductory authentic video about the unit or lesson's topic followed by an illustration of the grammar or vocabulary they were going to study in the lesson using the video as an example. It should be noted that all the videos had either captions or a video script available. Then, on another page they had more examples and/or an explanation about the lesson. Next, practice exercises and activities about what they just learned were provided. After that, the following part was about the workbook assignment with answers so they could go back to the platform to check their work. Lastly, they had a production focused activity about the whole lesson they studied where they had to combine the skills they learned in order to communicate fulfilling the goal of the lesson. The online 
lessons were planned and designed to adapt to the different types of learners' intelligences. For example, there were illustrations representing language for visual learners; videos for visual and auditory learners; explicit grammar figures for linguistic and visual learners; audios, pronunciation and repetition activities for auditory learners; video recording activities for kinesthetic learners; discussion forums for interpersonal learners; finally, most of the online lessons and activities that were to be completed individually for intrapersonal learners.

Figure 5

Module's Content

\begin{tabular}{|c|c|c|c|c|}
\hline 䇣 & : • Unit 6: Life Plans. Lesson 2 & $\bullet$ & + & $\vdots$ \\
\hline$\Leftrightarrow$ & 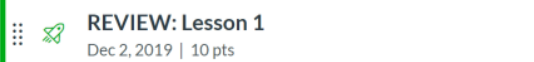 & & $\bullet$ & $\vdots$ \\
\hline $\begin{array}{c}\text { Accoun } \\
t\end{array}$ & :: 国 LESSON 2: Express regrets about past actions & & $\odot$ & $\vdots$ \\
\hline $\begin{array}{l}\text { Do } \\
\text { Dashb } \\
\text { oard }\end{array}$ & $\begin{array}{l}:: \text { GRAMMAR. Perfect modals } \\
\text { Dec } 2,2019\end{array}$ & & ○ & $\vdots$ \\
\hline $\begin{array}{c}\text { 㘣 } \\
\text { Course }\end{array}$ & $\begin{array}{l}:: \quad \& 8 \begin{array}{l}\text { A. Grammar Practice I } \\
\text { Dec } 2,2019 \mid 5 \text { pts }\end{array}\end{array}$ & & 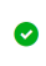 & $\vdots$ \\
\hline s & $\begin{array}{l}:: \$ 8 \text { B. Grammar practice II } \\
\text { Dec } 2,2019 \mid 5 \text { pts }\end{array}$ & & $\odot$ & $\vdots$ \\
\hline ar & :: PRONUNCIATION. Reduction of have in perfe & & $\triangle$ & $\vdots$ \\
\hline
\end{tabular}

Grammar lessons were presented with an introductory video, and then, with some illustrations about what the grammar lesson was going to be. Perceptual salience was an important factor in this part of each module since the purpose of it was for students to notice the language that was being used without any explicit grammar about it yet, but with the highlighting of certain grammar structures to draw their attention to them, as seen in Figure 6. 
Figure 6

Grammar Lesson Introduction

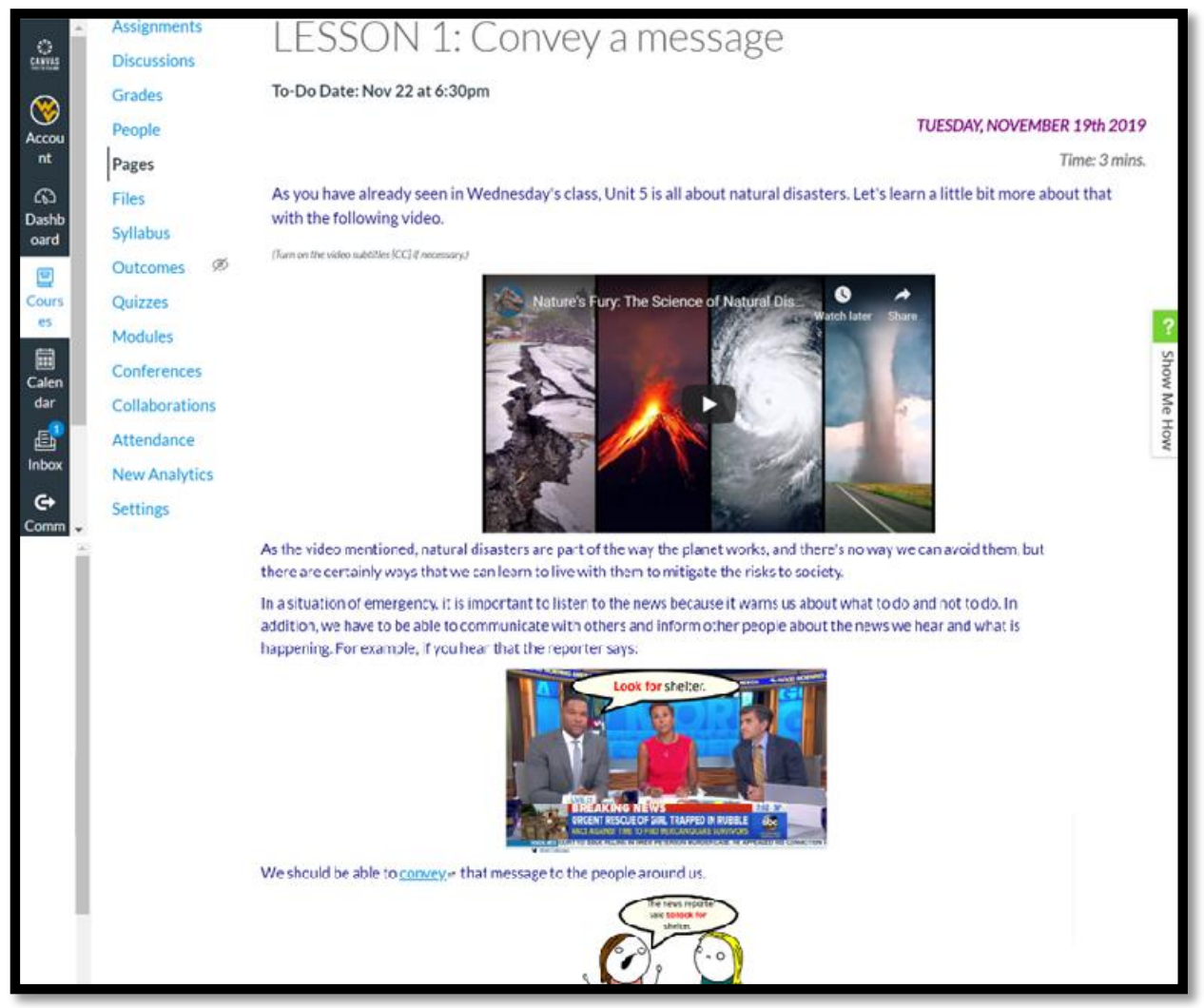

After the introduction, students were presented with several more examples which were accompanied by illustrations of explicit grammar, as shown in Figure 7. This grammar explanation was then followed by a grammar couch video that was part of the textbook materials that the institution receives. These videos are almost never used in class because they show a teacher explaining a grammar point, which might be considered too repetitive if there is an actual teacher in the classroom doing the same. 
Figure 7

Explicit Grammar

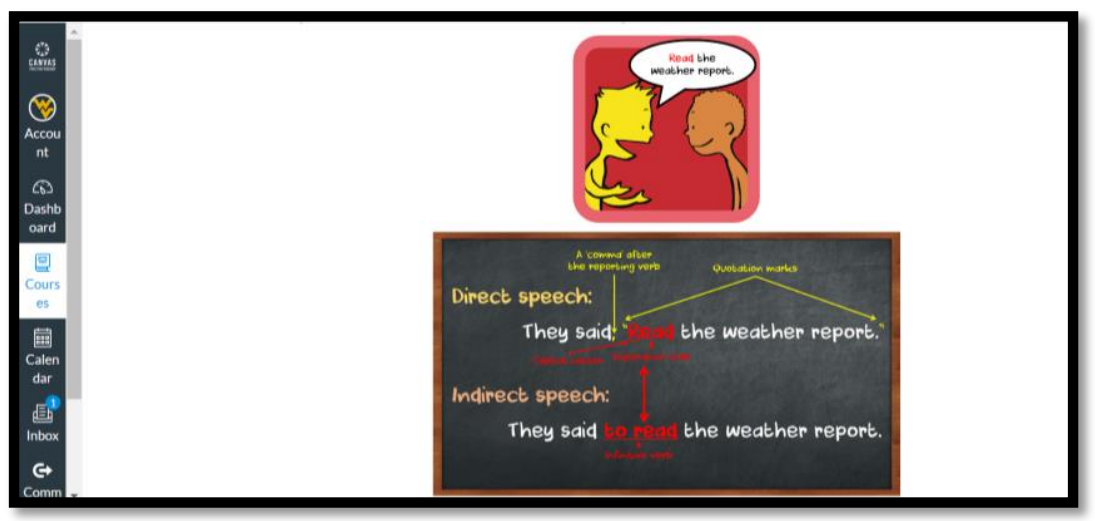

Once they finish with the explanation of the grammar or reading lesson, students are presented with several kinds of exercises to practice, as shown in Figure 8. Among the types of exercises, there were multiple-choice, sentence completion, one-sentence answer, true and false, and cloze exercises. Once the students completed the exercises, they received instant feedback from the LMS so they could analyze their mistakes. Since these were practice exercises, they were given more opportunities to re-do them without making the same mistakes.

Figure 8

Grammar Practice

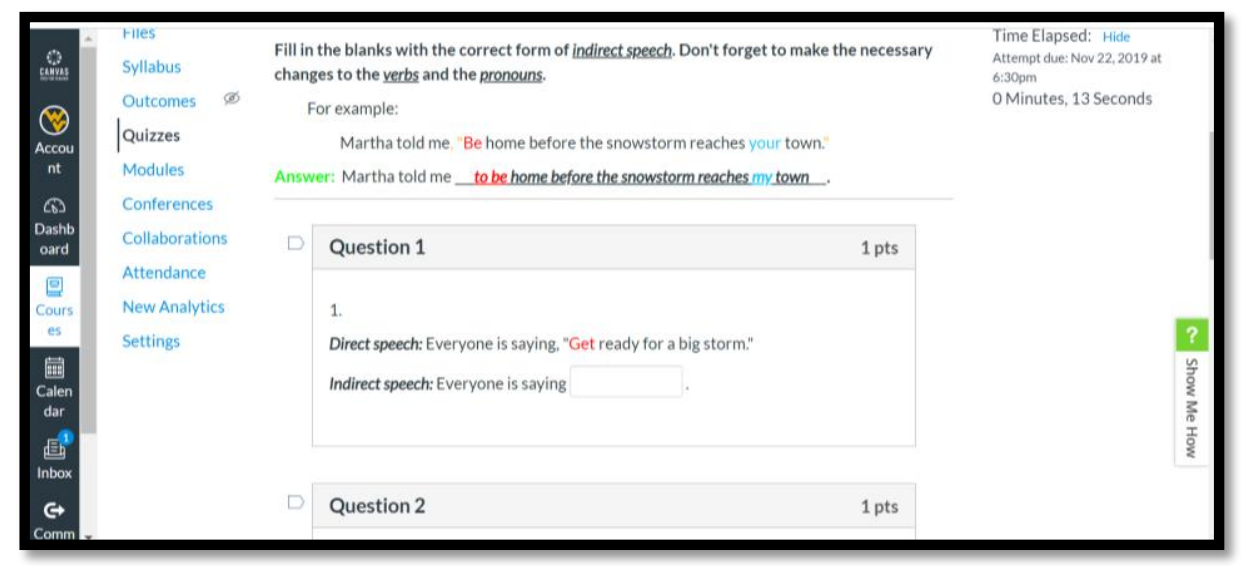

For pronunciation practice, as seen in Figure 9, they could listen to the different pronunciation types and read the examples at the same time; each audio also gave them the time to repeat afterwards. They also were presented with a video of the pronunciation coach from 
their textbook that used a different approach to teach them the pronunciation lesson. Finally, they had the option and suggestion to record themselves using the LMS to compare their pronunciation with the models.

\section{Figure 9}

\section{Pronunciation Practice}

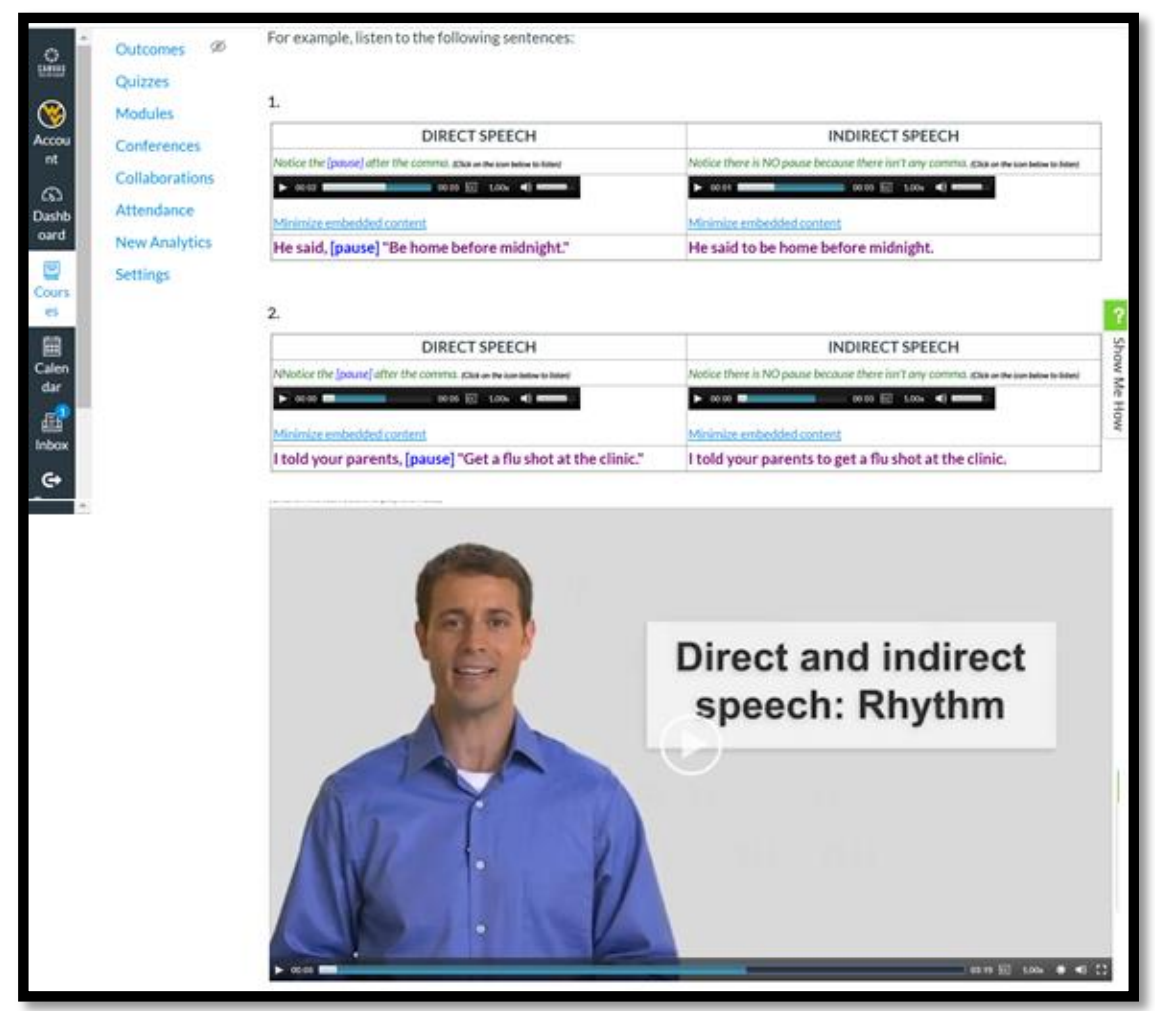

In the textbook, the lessons that were about grammar always had their communicative part with a conversation model that emphasized conversation strategies related to the lesson's goal. In this part, the students had the opportunity not only to listen to it, as they used to do it with the textbook, but also to watch the video of it, as illustrated in Figure 10. Then, they also had comprehension exercises about the conversation content, and about the pragmatics of it since they had the visual representation of the conversation. 
Figure 10

Conversation Strategies

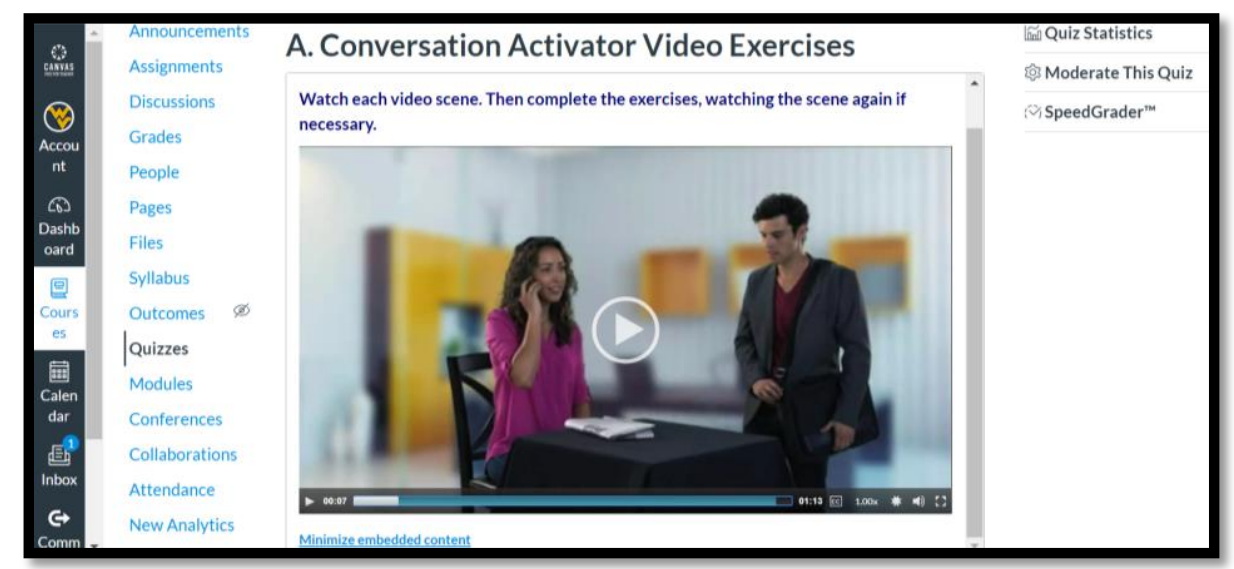

As shown in Figure 11, vocabulary lessons were more illustrated in the online course than they were in the textbook. For example, in the case of adjectives of severity, the textbook only had the list of adjectives with an intensity sign next to it: mild+, moderate++, severe+++, etc., but in the online lesson, more illustrations representing the vocabulary were added with their usage in order to improve understanding. Hyperlinks were also added to the vocabulary words, which sent them to the definition of the word in the Merriam-Webster dictionary website.

Figure 11

Vocabulary Lesson

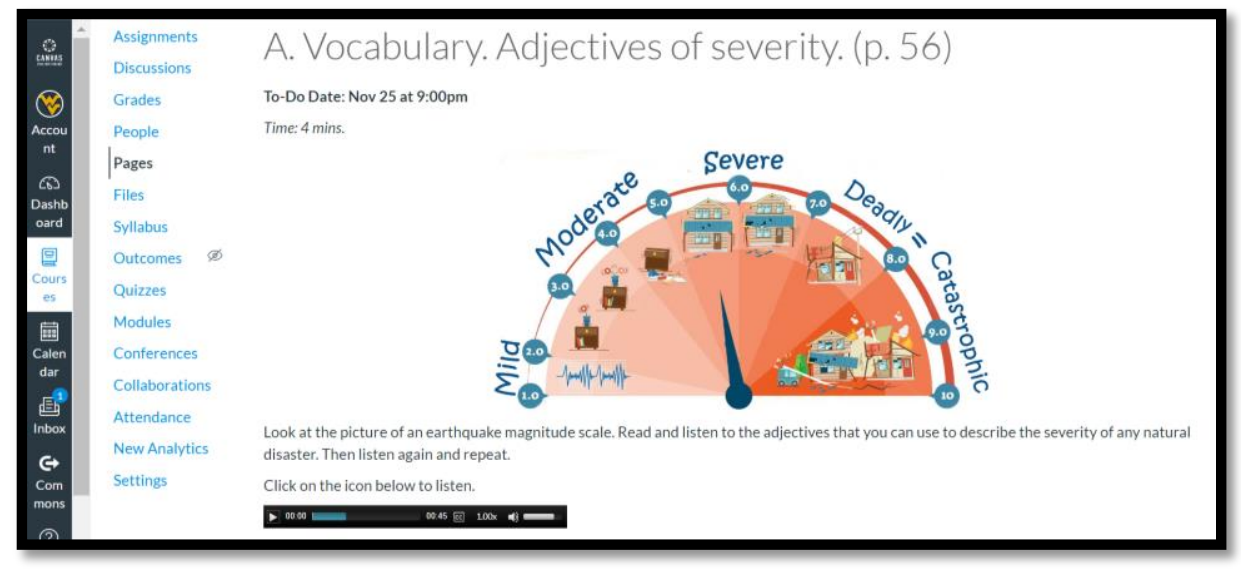

Each unit had one writing booster lesson fully dedicated to a writing strategy related to the lesson topic. As presented in Figure 12, students were presented with an example of the kind 
of writing they were expected to produce. Then, they had a small practice exercise about the strategy they were learning, and finally, they were asked to write a paragraph or paragraphs about what they just learned. They had to post that in the discussion part of the page to share with their classmates and received individual feedback from their teacher about it.

Figure 12

Writing Lesson

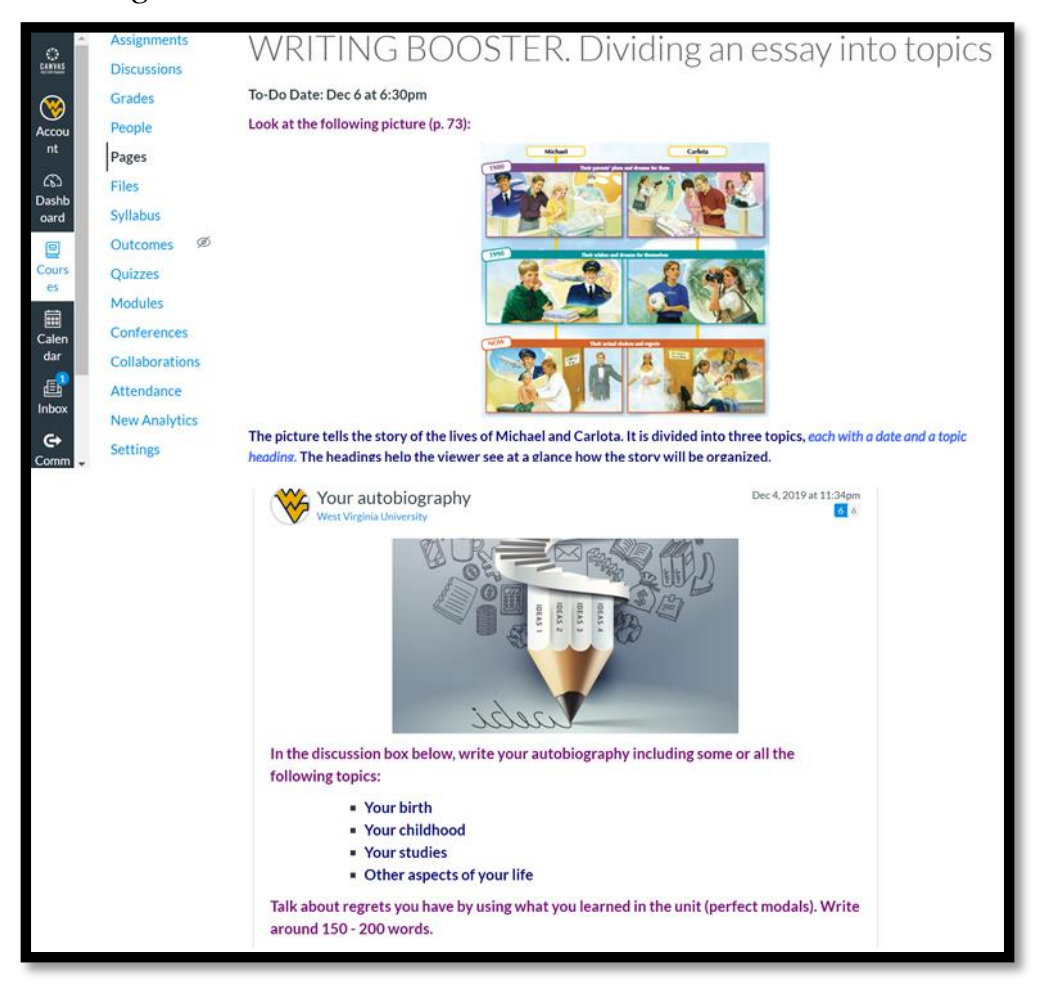

As it can be observed in Figure 13, in the case of the listening exercises, due to the distribution of the lessons, only grammar and reading focused lessons were assigned to be online leaving listening focused lessons to be during face-to-face instruction. However, they had the unit review part online where they had some listening exercises to complete, and also the conversation parts where they practiced the skill with the comprehension exercises all the time. 
Figure 13

Listening Practice

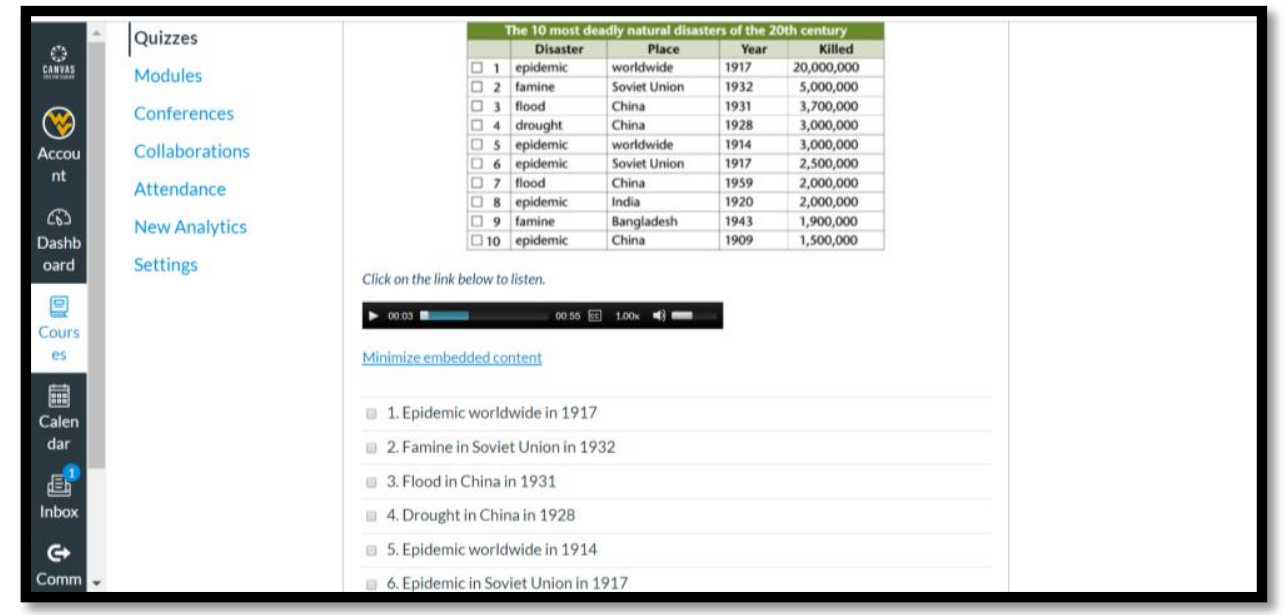

Since students had purchased the textbook and the workbook, they were meant to be used. Therefore, the workbook activities were completed in the experimental, blended learning group as well. As shown in Figure 14, the platform only provided them the answer key to it so after completing the lesson in the workbook, they could go back to it and check their work. The workbook is expected to be fully completed during the term, but sometimes it is not possible to do it in class, therefore, it is sometimes left as homework. There is also not a full correction or feedback about it because sometimes teachers run out of time in class. Nevertheless, in the online lessons, they had to complete everything and could self-correct their work all the time.

Figure 14

Workbook Activities

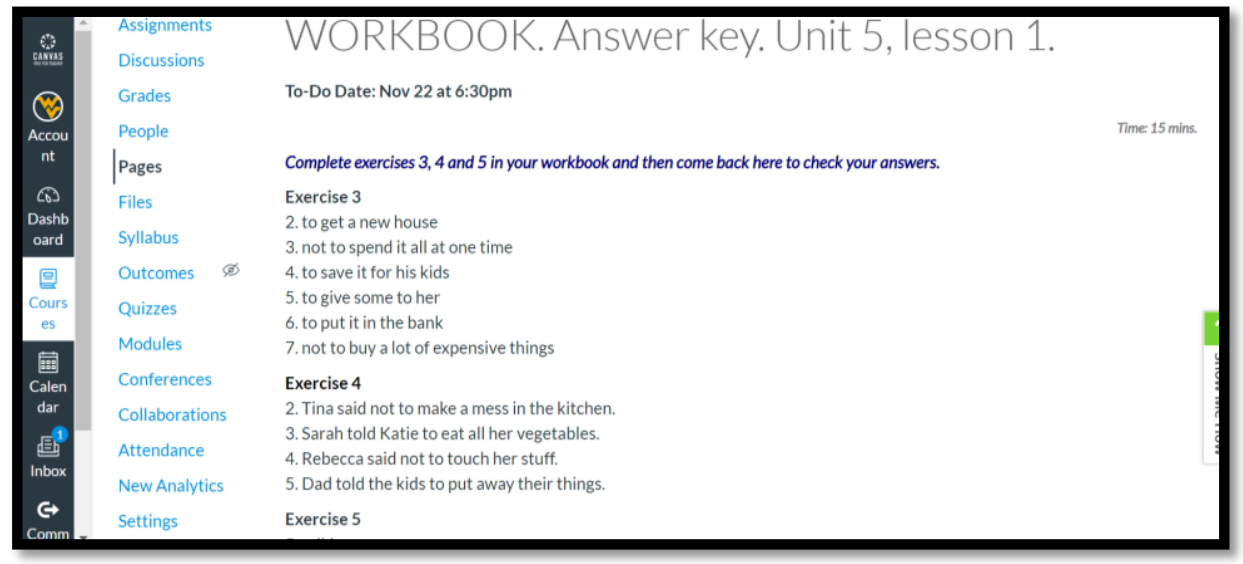


Each lesson had a language production activity about the lesson's goal. They had to put together the grammar, vocabulary, and the goal of the lesson in order to communicate what the goal said. For example, in the lesson shown in Figure 15, they had to use indirect speech and natural disasters vocabulary in order to convey a message from a news website. They also received direct feedback from the teacher in this activity.

Figure 15

Language Use Activity

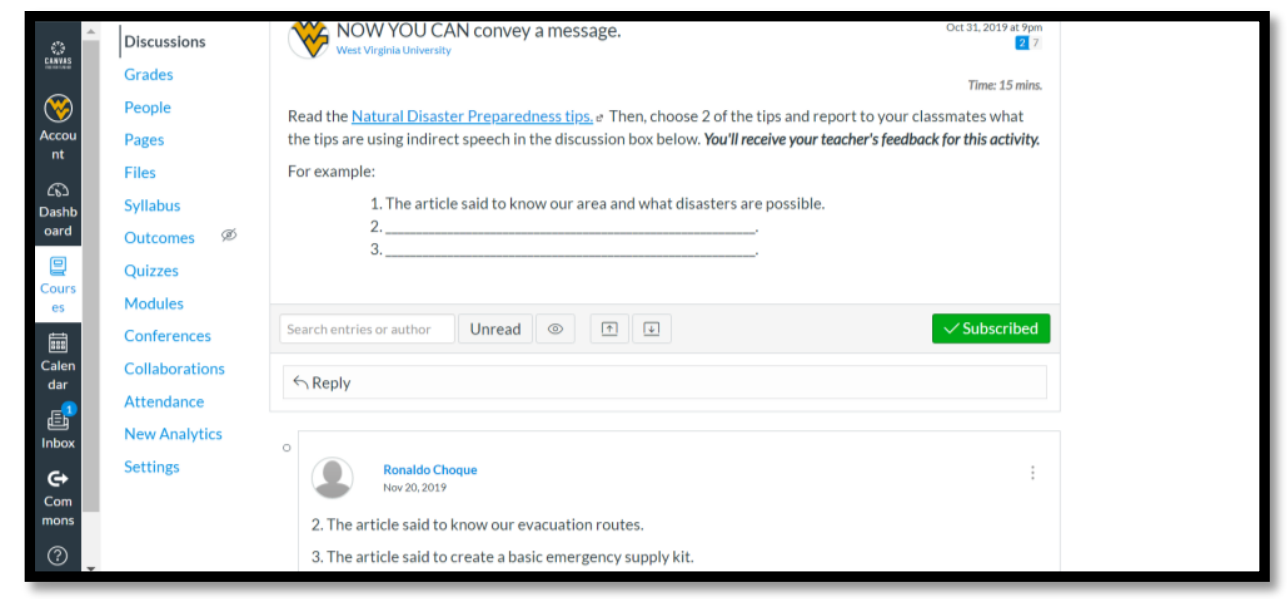

\section{Instruments}

In order to collect the quantitative data, the scores of their exams were used. These exams are designed by the institution's faculty for every level at their English program. To examine whether both groups had a similar language proficiency level at the beginning of the module, the results of their final exam about units 3 and 4 of the previous module were considered (see Appendix A).

Their learning proficiency level and outcomes in the skills mentioned before were collected through two quizzes—one about unit 5 and the other about unit 6-administered on the eighth and sixteenth days of the module, and the final exam-about both units (5 and 6) administered on the seventeenth day of the module. These exams comprised items with all the 
skills needed to be measured. Their grades were registered in the teacher's grade keeper to which the researcher had full access.

In the case of the qualitative data, interviews were conducted with the students of the treatment group (see Appendix B) and the teacher (see Appendix C) by another instructor at the institution. These interviews were semi-structured since they had a set of predetermined questions, yet the interviewer was free to follow up a question with additional questions that may have been required according to the answers they gave. The students' interview was translated to Spanish so they would not have a language barrier to express their answers (see Appendix D). As mentioned before, the interviews were about their attitudes, insights, and perceptions of using blended learning and its usefulness, practicality, and general satisfaction.

\section{Procedures}

The experiment was programmed to start on the twelfth term/module on October $23^{\text {rd; }}$; however, the twelfth term got canceled due to external reasons to the institution. ${ }^{1}$ Consequently, it was conducted during the thirteenth term of the academic calendar at the institution, that is, from November $18^{\text {th }}$ to December $6^{\text {th }}, 2019$. The scores of the final exam (pre-test) from the previous module were collected on the last day of class of the eleventh module on October $21^{\text {st }}$.

As mentioned before, the comparison group had their normal lessons at the institution, that is, they had face-to-face lessons for 1.5 hours from Monday to Friday. They studied the first unit of the module (unit 5 of the textbook) in the first eight days and the second unit (unit 6 of the textbook) from the ninth to sixteenth day of the module. Finally, on the seventeenth day, they took a final exam about units 5 and 6 . The treatment group followed the same distribution of days for each unit with the difference of having them online on Tuesdays and Thursdays. 
Lastly, the interviews were conducted by another instructor at the institution on the last days of the module, more specifically on December $6^{\text {th }}$. While the students were in class, they were requested to go one by one to have the interview with the other instructor in a separate classroom. It is worth saying that the instructor conducting the interview was previously trained to ask follow-up questions whenever necessary and made sure that each interview and timing was similar for each of the participants, lasting around eight to twelve minutes. The interviews were conducted in the participants' first language, Spanish.

\section{Data Analysis}

For the analysis of the qualitative data, the interviews, a simple content analysis was used in order to investigate not only their attitudes, but also if there are some factors that were not taken into account by the researcher that may support the quantitative data. For the analysis of the quantitative data, parametric statistics were used since the data were normally distributed. In order to compare the results of the exams between the comparison group and the treatment group, a two-way mixed ANOVA was used to compare their overall proficiency, and an independent t-test was used to compare their language proficiency level of each skill to examine whether the results of the comparison group and the treatment group differed statistically. Furthermore, a Levene's test for equality of variances was also conducted in the present analysis indicating a level of significance higher than 0.05 which means that it can be assumed that the distribution of test scores in the treatment group is similar in shape to the distribution of test scores for the comparison group. 


\section{CHAPTER 4}

\section{Results}

As mentioned in the literature review, the purpose of this study was to investigate whether there were significant differences in language proficiency between students in the blended learning group and students in the face-to-face learning group, as measured through performance in their tests, that is, the first quiz about unit 5, the second quiz about unit 6 , and their final exam about both units. Each test was divided by language skills; therefore, the score the participants got in each skill is what was used for the data analysis. The skills that were considered were 1) grammar and vocabulary, 2) reading, 3) listening, 4) writing, and 5) speaking, and the scores of all of them were out of $100 \%$.

In order to confirm that all students had a similar level, their final exam from the previous module was considered as their pre-test.

Table 1

Mean and Standard Deviation of Pre-Test Scores

\begin{tabular}{llcccc}
\hline Variable & \multicolumn{1}{c}{ Group } & $\mathrm{n}$ & $\mathrm{M}$ & $\mathrm{SD}$ & SEM \\
\hline \multirow{2}{*}{ PTS } & Treatment group & 13.00 & 65.92 & 11.69 & 3.24 \\
& Comparison Group & 18.00 & 64.86 & 10.93 & 2.58 \\
\hline
\end{tabular}

Note. $\mathrm{n}=$ Number of participants; PTS $=$ Pre-Test Scores out of 20 .

Table 2

Independent t-test of Pre-Test Scores

\begin{tabular}{lcccccc}
\hline & \multicolumn{7}{c}{ t-test } \\
\cline { 2 - 7 } Variable & $t$ & $d f$ & $p$ & $M D$ & $S E D$ & Cohen's $d$ \\
\hline PTS & 0.26 & 29.00 & 0.80 & 1.07 & 4.10 & 0.09 \\
\hline Note. PTS = Pre-Test Scores.
\end{tabular}

As it can be observed in Table 2, an independent-samples t-test was conducted to compare the groups' pre-test scores. There was not a significant difference in the scores of the treatment group $(\mathrm{M}=65.92, \mathrm{SD}=11.69)$ and the comparison group $(\mathrm{M}=64.86, \mathrm{SD}=10.93)$ as shown in Table $1 ; \mathrm{t}(29)=0.26, \mathrm{p}<0.80, \mathrm{~d}=0.09$. These results suggest that the scores of the 
pre-test from the treatment group are not significantly different from the comparison group; thus, it can be assumed that all the students had a similar language level when they started the study.

\section{Research question 1: Are there significant differences in overall proficiency between students in blended learning and students in face-to-face learning approaches?}

As shown in Table 1, the blended learning treatment group was composed of thirteen students, and the comparison group was composed of eighteen students. Table 3 shows the descriptive statistics of their overall scores on each test.

Table 3

Descriptive Statistics of Tests' Final Scores

\begin{tabular}{clccc}
\hline \multicolumn{1}{c}{ Variable } & \multicolumn{1}{c}{ Group } & M & SD & $\mathrm{n}$ \\
\hline \multirow{2}{*}{ FSQ1 } & Treatment group & 75.5 & 11.9 & 13 \\
& Comparison group & 85.0 & 10.1 & 18 \\
\hline \multirow{2}{*}{ FSQ2 } & Treatment group & 74.3 & 7.7 & 13 \\
& Comparison group & 86.5 & 10.0 & 18 \\
\multirow{2}{*}{ FSFE } & Treatment group & 76.4 & 9.2 & 13 \\
& Comparison group & 84.1 & 5.9 & 18
\end{tabular}

Note. $\mathrm{n}=$ Number of participants; FSQ1 = Final Score Quiz 1; FSQ2 = Final Score Quiz 2; FSFE = Final Score Final Exam.

From the mean data, it can be observed that overall the comparison group performed better than the treatment group on all three assessments. It can also be seen that the standard deviation is mostly higher for the treatment groups, except in the second quiz, which represents how far apart the highest and lowest score are from the mean. The fact that the standard deviation is mostly high in the treatment group means that there is also a considerable score difference between the highest score and the lowest score in the group. 
Table 4

Tests of Within - Subjects Effects

\begin{tabular}{llccccc}
\hline \multirow{2}{*}{ Variable } & \multicolumn{1}{c}{ Type III } & & & & \\
& \multicolumn{1}{c}{ Source } & SS & df & MS & F & p \\
\cline { 2 - 6 } Time & Sphericity Assumed & 0.32 & 2 & 0.16 & 0.002 & 1 \\
& Greenhouse-Geisser & 0.32 & 1.87 & 0.17 & 0.002 & 1 \\
& Huynh-Feldt & 0.32 & 2 & 0.16 & 0.002 & 1 \\
& Lower-bound & 0.32 & 1 & 0.32 & 0.002 & 0.96 \\
\hline \multirow{2}{*}{ Time * } & Sphericity Assumed & 78.65 & 2 & 39.33 & 0.54 & 0.59 \\
Group & Greenhouse-Geisser & 78.65 & 1.87 & 42.15 & 0.54 & 0.57 \\
& Huynh-Feldt & 78.65 & 2 & 39.33 & 0.54 & 0.59 \\
& Lower-bound & 78.65 & 1 & 78.65 & 0.54 & 0.47 \\
Error & Sphericity Assumed & 4215.42 & 58 & 72.68 & & \\
(Time) & Greenhouse-Geisser & 4215.42 & 54.11 & 77.90 & & \\
& Huynh-Feldt & 4215.42 & 58 & 72.68 & & \\
\hline
\end{tabular}

Note. $S S=$ Sum of Squares.

In order to investigate whether the differences between the groups and over time was statistically significant, a mixed between-within ANOVA was conducted. As presented in Table 4, there was not a significant effect of time, $\mathrm{F}(2,58)=0.02, \mathrm{p}<1$, nor a statistically significant two-way group-time interaction effect between the three exams, $F(2,58)=0.54, p<0.59$.

- SQ1.1: Are there significant differences in grammar and vocabulary between students in blended learning and students in face-to-face learning approaches?

Table 5

Mean and Standard Deviation of All Skills Final Exam's Scores

\begin{tabular}{llcccc}
\hline Variable & \multicolumn{1}{c}{ Group } & $\mathrm{n}$ & $\mathrm{M}$ & $\mathrm{SD}$ & $\mathrm{SEM}$ \\
\hline \multirow{2}{*}{ GVFES } & Treatment group & 13.00 & 81.86 & 12.39 & 3.44 \\
& Comparison Group & 18.00 & 83.16 & 9.29 & 2.19 \\
\hline \multirow{2}{*}{ RFES } & Treatment group & 13.00 & 92.30 & 11.01 & 3.05 \\
& Comparison Group & 18.00 & 95.37 & 11.14 & 2.63 \\
\hline \multirow{2}{*}{ LFES } & Treatment group & 13.00 & 66.92 & 25.94 & 7.20 \\
& Comparison Group & 18.00 & 89.44 & 15.14 & 3.57 \\
\hline \multirow{2}{*}{ WFES } & Treatment group & 13.00 & 61.54 & 14.05 & 3.90 \\
& Comparison Group & 18.00 & 64.78 & 8.35 & 1.97 \\
\hline \multirow{2}{*}{ SFES } & Treatment group & 13.00 & 79.69 & 6.97 & 1.93 \\
& Comparison Group & 18.00 & 87.64 & 9.49 & 2.24 \\
\hline
\end{tabular}

Note. $\mathrm{n}=$ Number of participants; GVFES = Grammar and Vocabulary Final Exam Score; RFES = Reading Final Exam Score; LFES = Listening Final Exam Score; WFES = Writing Final Exam Score; SFES = Speaking Final Exam Score. 
Table 6

Independent t-test of Grammar \& Vocabulary Final Exam's Scores

\begin{tabular}{lcccccc}
\hline & \multicolumn{7}{c}{ t-test } \\
\cline { 2 - 7 } Variable & $t$ & $d f$ & $p$ & $M D$ & $S E D$ & Cohen's $d$ \\
\hline GVFES & -0.33 & 29 & 0.74 & -1.3 & 3.89 & 0.11 \\
\hline Note. GVFES = Grammar and Vocabulary Final Exam Score.
\end{tabular}

In order to answer the sub-questions of the first research questions, the same independent samples t-test was conducted for each of the skills. Means (with standard deviations in parentheses) of the treatment group and comparison group for the grammar and vocabulary final exam's scores were 81.86 (12.39), and 83.16 (9.29), respectively, as shown in Table 5. The independent-samples t-test, presented in Table 6, was $\mathrm{t}(29)=-0.33, \mathrm{p}<0.74, \mathrm{~d}=0.11$. These results suggest that there is not a statistically significant difference between the mean score sof both groups' grammar and vocabulary final exam.

- SQ1.2: Are there significant differences in reading skills between students in blended learning and students in face-to-face learning approaches?

Table 7

Independent t-test of Reading Final Exam's Scores

\begin{tabular}{lcccccc}
\hline & \multicolumn{7}{c}{ t-test } \\
\cline { 2 - 7 } Variable & $t$ & $d f$ & $p$ & $M D$ & $S E D$ & Cohen's $d$ \\
\hline RFES & -0.76 & 29 & 0.45 & -3.07 & 4.04 & 0.27 \\
\hline Note. RFES & Reading Final Exam Score.
\end{tabular}

As presented in Table 5, mean scores (with standard deviations in parentheses) of the treatment group and comparison group for the reading final exam scores were 92.3 (11.01), and 95.37 (11.14), respectively. The independent-samples t-test, presented in Table 7, was t (29) = $0.76, p<0.45, d=0.27$. These results suggest that there is not a statistically significant difference between the mean score of both groups on the reading final exam. 
- SQ1.3: Are there significant differences in listening skills between students in blended learning and students in face-to-face learning approaches?

Table 8 Independent t-test of Listening Final Exam's Scores

\begin{tabular}{lcccccc}
\hline & \multicolumn{7}{c}{ t-test } \\
\cline { 2 - 7 } Variable & $t$ & $d f$ & $p$ & $M D$ & SED & Cohen's $d$ \\
\hline LFES & -3.05 & 29 & 0.005 & -22.52 & 7.4 & 1.06 \\
\hline Note. LFES & Listening Final Exam Score.
\end{tabular}

Mean scores (with standard deviations in parentheses) of the treatment group and comparison group for the listening final exam scores were 66.92 (25.94), and 89.44 (15.14), respectively, as indicated in Table 5. The independent t-test, as shown in Table 8, was t (29) = $3.05, p>0.005, d=1.06$. Since the level of significance is below .05 and the effect size is considerably large, these results indicate that the comparison group performed significantly better than the blended learning group on the listening final exam.

- SQ1.4: Are there significant differences in writing skills between students in blended learning and students in face-to-face learning approaches?

Table 9 Independent t-test of Writing Final Exam's Scores

\begin{tabular}{lcccccc}
\hline & \multicolumn{7}{c}{ tndependent $t$-test of Writing Final Exam's Scores } \\
\cline { 2 - 7 } Variable & $t$ & $d f$ & $p$ & $M D$ & $S E D$ & Cohen's $d$ \\
\hline WFES & -0.8 & 29 & 0.42 & -3.24 & 4.03 & 0.28 \\
\hline Note. WFES & Writing Final Exam Score.
\end{tabular}

As shown in Table 5, the means (with standard deviations in parentheses) of the treatment group and comparison group for the writing final exam scores were 61.54 (14.05), and 64.78 (8.35), respectively. Results of the independent t-test was $t(29)=-0.8, p>0.42, d=0.28$, which means that the difference between the mean score of both groups is not statistically significant because the level of significance is above .05, as shown in Table 9. 
- SQ1.5: Are there significant differences in speaking skills between students in blended learning and students in face-to-face learning approaches?

Table 10

Independent t-test of Speaking Final Exam's Scores

\begin{tabular}{lcccccc}
\hline & \multicolumn{7}{c}{ t-test } \\
\cline { 2 - 7 } Variable & $t$ & $d f$ & $p$ & $M D$ & SED & Cohen's $d$ \\
\hline SFES & -2.56 & 29 & 0.01 & -7.95 & 3.11 & 0.95 \\
\hline Note. SFES & Speaking Final Exam Score.
\end{tabular}

Tables 5 and 10 show the data about the final exam's speaking section score. Means (with standard deviations in parentheses) of the treatment group and comparison group for the speaking scores were 79.69 (6.97), and 87.64 (9.49), respectively. Results of the independent ttest was $\mathrm{t}(29)=-2.56, \mathrm{p}>0.01, \mathrm{~d}=0.95$, demonstrating that there was a significant difference between the mean scores of both groups, with the comparison group performing significantly better than the blended learning group.

In sum, the results of research question 1 demonstrated that students' scores from the treatment group were not significantly different from the comparison group in the case of grammar and vocabulary, reading, and writing. In contrast, there was a statistically significant difference with respect to the skills of listening and speaking, with the comparison group performing better.

\section{Research question 2: What are the students and teacher's attitudes towards the blended learning approach in comparison to their regular face-to-face lessons?}

In order to examine this research question, students from the treatment group were interviewed by a different instructor at the language institution (see Appendix B for the interview questions). The interview's goal was to gather the students and teacher's attitudes towards the blended learning program they experienced. Questions 1, 5, and 6 emphasized the influence that 
the online tools had on their learning. Question 2 and the follow-up of question 6 were about the difficulties they experienced in the online course and the elements that they did not find helpful for their language learning. Questions 3 and 4 were about the effect that the online lessons had on their communication skills, written and spoken. Finally, question 4 was about the opportunities of self-feedback that they had, and the opportunities of reflecting on their own skills.

\section{Tools' positive influence on language learning.}

Students mentioned several online tools and characteristics of the platform that influenced their language learning in a positive way. Among these, most of them mentioned the videos that were used to introduce some lessons and discussion boards because they considered themselves visual learners, or because it was a different way of introducing a lesson since in class, they usually do not have the time to do it often. Participant 1 said, "Sometimes I am the kind of person who learns more by watching, so the videos help me understand some things, see, inform myself more, and learn a lot of new words."

Audiovisual materials are often appealing to students because of their authenticity; however, sometimes there is not enough time in a class for teachers to use them. For instance, Participant 4 affirmed, "I found useful the articles and videos they gave us when we started some new topic. They were different from the book and about what had happened in other countries." Participant 13 agreed by saying, "We can see some videos and listen to some audios that we cannot see in the course for lack of time. I think they helped a lot to the understanding especially of those that already have some knowledge of English or the students who learn a little faster since they can maybe do it in much less time and save more time." Two participants agreed about the importance of this kind of materials too. Participant 5 stated, "I think the videos are a 
very important part because, in addition to being visual, you can listen to them, so you improve your ability to understand the language much better. When some words were not understood, the English subtitles could help you with the part or word that was not clear so you could have an idea about it or look for it." Participant 8 also said, "I liked the videos and audios because that is not something you find in the book and when you see more fluid conversations you learn not only by reading." One of the students found the authenticity in the videos very useful for their future-selves. Participant 11 said, "The videos where we had to comment were very useful because at some point in my life, I think I will have a similar situation where they only speak in English so I will know how to express myself and comment using the language from the videos as an example." A feature that is possible with most online video players is that most of them have English captions and there is also the possibility of making them play slower or faster, a feature that participant 10 found useful by saying, "CANVAS had the option to make the audios and videos slower, so whenever you could not listen to it well, you could make it a little slower, and I liked that."

Another common useful feature of the online platform for many participants was the way grammar was presented and the amount of practice they had with it. Since they did not have a teacher to explain some grammar lessons because they had to be online, a lot of imagery representing examples was used to teach them how the grammar structures worked. Moreover, they also had the grammar couch videos and the extra grammar exercises, besides the ones they had in the textbook. All these extra materials were not possible to be used in the face-to-face lessons due to the fact that the time to finish a lesson in the book and the workbook is 90 minutes, which is not enough to include all the mentioned material. Some participants mentioned that grammar was easier to understand, because whenever they could not understand it, they 
could always go back to the explanation as many times as necessary for each of them, something that it is not always possible to do in a classroom due to the time factor. This is because the teacher sets the pace in the classroom. That is, the teacher can solve doubts, but will not always spend the whole class on it, or there will always be shy students who will not say they did not understand some part of the lesson. For example, participant 6 mentioned, "The platform was useful mostly to learn grammar because each structure was well specified and explained with examples." Participant 7 also said, "I think technology always influences language learning more, so I was able to understand (the grammar) better, and if I didn't understand, I could go back to review as many times as I wanted." Similarly, participant 11 stated, "The platform has helped me a little more because it makes us practice, that helps us also, so at the same time I learned more (...) Also the practice itself gave us many opportunities to keep trying and trying." Participant 2 also mentioned, "It was good to have the possibility of being able to do all the exercises that we could not do in class because of time, and maybe those exercises can be important." Lastly, participant 9 said, "The way in which each exercise was described was very easy to understand and the time it gave us to do the exercises was unlimited." They also mentioned the kind of exercises they were given to practice the grammar they just learned. While some of them mentioned they liked the multiple-choice exercises, such as participant 5 who said, "I liked best the multiple choice exercises, because they were faster to do and also showed you immediate results, so then you could correct them again and do it well." Others mentioned they liked the open-ended questions, such as participant 3 who said, "I liked the extensive exercises; those that helped you develop writing because the vocabulary and writing part combined helped us a lot." 
Among other general opinions, participant 6 mentioned, "The platform progress report, the calendar, and the notifications of the activities you were missing reminded us to keep working." This is a very simple feature of most online platforms and occasionally underestimated, but at the same time, very useful for students to keep track of their progress. Some participants also mentioned the efficiency of online lessons regarding the flexibility of when and where they could complete the lessons; for example, participant 9 affirmed, "I could practice at home at any time and in my spare time. That helped me remember quite a bit what we did in class." Participant 12 said, "The fact that you can log in any moment, complete everything at any time, and in your home, technically, was more comfortable, especially for the people who live far from the institution like me." Finally, a participant mentioned the voice recording as a very useful tool to practice speaking. Participant 13 stated, "The most useful tool for me was the one about sending recordings since for that you need to plan and have the context of what you are going to say because you cannot be sending stuttering or stopping, so it forces you to prepare it and do it correctly since you have to read it fluently so that you and everybody can understand it."

\section{Online course difficulty and not helpful elements.}

While implementing new online learning tools and new elements to their regular English lessons, students encountered some difficulties and some elements that according to them were not helpful. There were also hindering circumstances beyond the structure of the lessons which will be discussed in Chapter 5. This section will focus only on those related to the blended learning aspect of the class.

A difficulty that many of them mentioned the most was the fact that they did not have a teacher who was there to help them while completing the lessons. For example, participant 5 
said, "With your teacher, if you have any doubts you can consult him immediately to clarify those doubts, but not on the platform." Participant 6 also added, "In class you can ask at that moment, but when you are using the platform, you don't know who to go to, so you have to read again and teach yourself". Participant 8 made a similar comment, "Although it has the grammar part with some examples, if you don't understand it you have to reread it until you do it, but with a teacher you can really ask as many times as you want until you get to understand." The students also emphasized the fact that a teacher would find and try different ways and examples to solve a doubt, while in the platform that was limited to the content it had. About this, participant 3 mentioned, "If you have a question you can go online and look for it, but it is not the same as someone explaining and showing it to you with plenty of examples until you understand." Participant 13 also said, "If in class you don't understand with an example, the teacher can give you another not only easier explanation, but also infinite examples, something that a program may never be able to do."

Another common disadvantage that students agreed on was the fact that all the responsibility of completing the tasks on their own at home was on them. They mentioned that in a regular class they are mostly focused and encouraged to work because of the environment of the classroom that surrounds them. However, with the online platform, it was their responsibility to organize their time and complete the modules on their own, which is something they found challenging. Participant 4 said, "With CANVAS, you didn't have a fixed schedule like when you go to class, so sometimes you ended up completing it at the last minute because of distractions." To this, participant 7 added, "It's hard to have a schedule and not to complete the tasks messily. Having those routines is a difficult thing." Participant 13 said, "CANVAS needs a lot more concentration than in a face-to-face class because if you are in your home or using the cell 
phone, there are many things that can distract you and if you want to learn you need to be extra focused." Their time management was also a difficulty for them since they had other responsibilities too, such as participant 10 who said, "The issue of time is complicated as sometimes I had many things to do." Participant 3 who added, "The amount of time that needed to be invested in the online lessons was hard to manage because of the accumulation of school homework and exams I had after the strike" (See Footnote 1 for more information).

One of the grammar points was about direct speech, and students were going to be assessed not only in the use of it but also in the writing of it; thus, the evaluation was strict in correcting the punctuation of direct or quoted speech. This was something some students found difficult since the platform corrected every single part of punctuation in their direct speech statements, and it was not something they were used to. About this, participant 1 said, "The part where you have to add the punctuation correctly was difficult because if you were wrong about a period or a comma, the whole answer was wrong, and you had to do it again. I believe punctuation was not as important as the language that was there, but it would always correct you as wrong if something was missing." Participant 13 added, "It was difficult the fact that you had to give an exact answer, and that no other variations were possible."

Among some other external issues, participant 1 mentioned that she felt a lot of visual fatigue for being in front of the computer for a long time. She also mentioned that there were some students who had problems with getting the necessary resources, such as a reliable internet connection or device, and enough time to complete the online lessons. Then, participant 8 mentioned that at certain times, videos loaded very slowly, and also that some exercises were longer and that they had to pay much more attention than to those in the class. Lastly, participant 
13 mentioned that the exercise where they had to report some news by recording an audio or filming themselves was something that he did not feel comfortable with.

\section{Communication skills effect.}

In this matter, most of students agreed that the platform gave them more opportunities for written communication rather than oral communication. Among the positive comments about how the platform helped their writing skills, students emphasized how helpful the discussion boards were where they had to give an opinion or tell a personal experience regarding the topic of the lesson. Participant 1 said, "I liked the tool that asks you for an opinion about some experience where you have to write, and then it takes you to a forum where you can share it." Participant 8 also said, "The final parts of each topic that asked for your opinion or point of view about your past experiences were good because you had to try to identify yourself with those topics, and then you could share it and also see your peers' responses too." Moreover, participant 13 added, "I found the conversations at the end of each lesson useful since you could post your answer and see each other's answers. The truth is that being able to talk to other people is very good because I was asked for more by having to answer the questions with my own words, so that forces you to expand the vocabulary you have."

On the other hand, most of students also agreed that it is not possible for online lessons to give opportunities for oral communication since you do not have classmates or a teacher with whom to start a conversation. About this, participant 2 stated, "Talking to me is very important and the lack of it is the biggest disadvantage from the platform. Yes, you can learn with the platform at home, but you don't get to practice your speaking that much.” To this, participant 9 also added, "The practice was a little more difficult because the application gave you more material for the writing part, and there was not any practice for the oral communication." Some 
students also mentioned that this disadvantage made them prefer face-to-face lessons because at the end their goal is to communicate in English. For instance, participant 3 said, "I prefer more the face-to-face class because here you have the opportunity to talk to the teacher." Participant 4 added, "I don’t think it was good for communicating in English. It (the platform) has been more useful as a learning method rather than an opportunity to communicate. To communicate, I'd prefer face-to-face classes." There were also a few positive comments about oral communication since some of them agreed that although the platform did not give them too many opportunities for speaking, it gave them examples, vocabulary and models on how to do it. Participant 11 mentioned, "It (the platform) prepares you more for when you're in a situation where you really need to express your English and you don't have to wait for an example to do it later for yourself." Lastly, participant 1 affirmed, "I have learned new vocabulary to be able to communicate, but beyond that, no."

\section{Reflection and self-feedback on their own skills.}

Plenty of students agreed that a positive aspect of the online platform was that it gave them the opportunity to get instant feedback after completing the grammar and vocabulary practice exercises, and that besides that, they were able to realize their mistakes, go back, and make the necessary corrections at their own pace. For example, participant 6 mentioned, "There are more exercises and more practice, and when I thought I understood something, I realized I was wrong, so the platform helped me to notice what my mistake was and the reason for it." Participant 11 also said, "The platform is something that helps you in a more direct way and the good thing is that it gives you opportunities to do it again, so then you learn from the mistakes and that is better." Participant 13 also added, "One very good thing it had was that you could do the exercises again, so if you had the wrong answer you could do it again and with that help you 
were able to improve because it gives you instant feedback. My results were better after going back to the examples." They also mentioned that the platform allowed them to work on their own trying to understand the lesson and finding strategies to do so. Participant 2 said, "When you do these tasks online you realize that you're making a lot of mistakes in writing and this is not something you usually realize in face-to-face lessons because the teacher cannot correct our writing all the time." Participant 7 also mentioned, "It helped me a lot because I could see for myself how something should be written instead of this being explained to me." Lastly, participant 10 added, "Since the teacher is not here to tell you that something is wrong, this is a good thing because you are totally forced to use your knowledge without hesitation and put it into practice."

Regarding the reflections they had on their own skills, students mentioned some of the aspects, activities, and tools of the platform that helped them the most to keep track of their language level and process. About the activities, P2 mentioned, "There was a task where an audio had to be recorded and I think that has helped me a lot to realize the level that I have. Even by watching the videos and how people talked, I realized that I was mispronouncing a few words, so all that has obviously helped me to speak in a better way." About the tools, participant 4 said, "The platform sometimes used different material that was not in the book and because it was something new, I had to think in a different way at that moment to try to solve the questions and problems they gave us." To which participant 7 also added, "I could learn faster than I learn in face-to-face classes because I had all the tools I needed. It was easy for me.” About some other aspects of the platform, participant 13 said, "I noticed that some classmates might have not have much enthusiasm about this new way of learning because of some of their short answers, but even then, they used so much new vocabulary for me in their answers, which made me 
realize that it actually helped me. Also, when I had to talk about my experiences, I pushed myself and wrote it considering how far my level reached."

Finally, there were also plenty of students who found the direct speech punctuation correction very useful since it was a language feature they did not consider important before. Participant 1 said, "I realized more about the punctuation like using quotation marks and capital letters which is very important, and also some things that were not clear to write, you learned with the program." Participant 3 also added, "Maybe I don't write very well in English and on the platform, I am forced to do so; for example, to use quotation marks, periods and commas. It has really helped me change that in the writing part." Participant 6 said, "It also tells you where you need to capitalize and add punctuation, which makes you notice errors in that matter." Participant 4 described it as a challenge by saying, "I was able to reflect on my writing because while giving the written answers, one can realize that if you did not write a period or the quoting marks, it was considered an error, which was a challenge to be careful about it the next time."

These four aspects summarize the attitudes that students had towards their blended learning lessons after experiencing it. It should be noted that they were not informed completely about what this research is looking for, which might be a reason why their answers are more focused on the online lessons rather than the combination of online and face-to-face lessons.

\section{Teacher's attitudes towards blended learning.}

The teacher that was chosen to teach both the comparison group and treatment group was known at the institution for usually integrating technology into his classes. He confirmed this in the interview because he said that he had participated in some seminars about using technology in classes; therefore, he usually tries to incorporate it in order to make the class is a little bit more comfortable for his students. He observed that sometimes it is hard for students to go to class 
every day because of their schedules or their occupation so in order to keep them practicing he tries to reach them outside the classroom through technology.

He also added that the integration of technology can enhance language teaching depending on the way one applies it. He said, "I think it is more dynamic in the aspect that sometimes it is hard, as a student, to solve some doubts when they are in class because of fear from their classmates or even from the teacher's judgment, so they do not ask things at that moment and wait for another time to do that, so I have seen that with some online tools they can actually do that feeling more comfortable."

The teacher also mentioned that sometimes there might be an extra burden caused by the integration of technology at the beginning, especially when students are becoming familiar with the new tool, as they did with CANVAS. However, he also said that once you are passed that difficult part, one can start seeing ways to improve and modify the tool to the students' needs.

Concerning his experience with the module in a blended format, he said that an effective element was the idea of students guiding themselves step by step through the online lessons which helped them to reach a better understanding of the lesson, and in some cases, to reinforce whatever was not so clear for the face-to-face lessons most of the times. He also mentioned that there were a lot of exercises that helped the students go through the lesson and when they had some doubts, they would go again and read or listen to the explanations of the grammar part one more time and do the exercises again, making the process very dynamic. Nonetheless, he admitted that there were moments in which sometimes students faced a situation where they needed an explanation about some rules giving as an example the fact that English is somewhat complicated because there are exceptions within the rules and when they have a doubt they need somebody to help them over that. As well as the students, the teacher believes that the situation 
where students encounter a doubt and need an immediate answer about it is something that has always happened and has not been able to be fixed yet in asynchronous online lessons.

In sum, the results from research question two indicated that most of students found the interactive side of the online lessons useful for their learning. They also agreed that the immediate feedback and opportunities to go back and re-do practice activities helped them to learn from their mistakes. On the other hand, most of them emphasized that the fact of not having a teacher to solve their doubts immediately was an issue; moreover, they mentioned as well that working by themselves under their own responsibility was challenging since they are used to be in a learning environment where they depend on a teacher who will guide them through a lesson and make them complete it no matter what. 


\section{CHAPTER 5}

\section{Findings and Discussion}

\section{Summary of Findings}

The results of the quantitative data presented in chapter 4 (research question one), overall showed that the comparison group performed better than the treatment group on some of the individual skill tests. Tables 3 and 4 displayed the mean scores on the different tests and results of a mixed ANOVA demonstrated no interaction between both groups' overall proficiency scores over time. These results are different from the study of Bañados (2006) where the participants showed an overall improvement in their language skills.

In the case of grammar and vocabulary, there was not a significant difference between the scores of both groups. This result can be related to what many students said about learning grammar and vocabulary in the platform. In the interviews, they mentioned that they found the platform useful since it allowed them to go back to the explanation as many times as they wanted, a fact that can be observed in the evidence provided by the quantitative data. This result is similar to the study of Tayşı and Başaran (2018), where according to the interviews, students found the online platform they were using useful for grammar and vocabulary.

The same situation happened with the skill of reading. There was not a statistically significant difference between the scores of both groups according to the t-test results and the small effect size. In the same way, in the interviews, students explained that they did a lot of reading in the platform because the instructions were written, they had captions in the videos, they had other people's comments to read, and they also had some short articles to read about some specific topics about the lesson. All this practice they had, not only with the exercise, but 
also with the general format of the platform may have had an impact on their results to be not significantly different from the comparison group.

In contrast, the statistics indicated that the scores on the skills of listening, writing, and speaking were significantly different between both groups, showing that the comparison group performed better than the treatment group. In the study of Gleason (2013), participants had more opportunities to communicate in the face-to-face lessons rather in the online lessons. Likewise, in the present study, some of these results were further supported by the students and the teacher since they mentioned that, in the case of the speaking, students did not have enough opportunities to communicate in the platform since everything was mainly based on reading and practicing grammar through different online tools.

\section{Discussion}

Overall, it can be observed that the comparison group performed better than the treatment group, more specifically in the skills of listening and speaking. However, in the case of listening, we cannot assume that the results were reliable since in the treatment group, there were two students who did not take the listening part because they were late for the exam. As a result, they had a zero in that section which substantially affected the group's mean score and standard deviation causing the result of having a significant difference between both groups' scores. The present study is also not considering other aspects that may have affected the performance of students such as attendance. In regular face-to-face lessons, students usually miss some classes for personal reasons, and regarding the language institution, they only allow students to miss up to four classes in a module (e.g., they have to attend at least thirteen out of seventeen days of instruction). In the case of the blended program, the study did not consider that rule; therefore, students were allowed to miss four classes out of eleven, that is, they had to attend at least seven 
out of eleven classes. According to the teacher's records, students from the treatment group had more absences than the comparison group. Thus, if we add to that the fact that they only had classes 3 times a week, it can be assumed that it is an important detail that may have affected the results.

Another important detail was that the students were not informed about the goals of the research. This was in order to stop students from studying or performing differently than they would usually. According to them, they were only volunteers to try a new teaching methodology at the institution. Although they were volunteers, they did not have a real necessity of being part of the blended program. As mentioned in Driscoll (2002), a blended learning program is mostly directed to people who do not have the time or the convenience to attend a class every day. In the case of the participants of this study, there was only one student who said that the program was appropriate for her because she lived too far from the institution, so the program saved her some time by allowing her to have some of the lessons at home. If the blended class consists of students who have a real need for this method, the issues of time management, distraction, organization and procrastination could potentially reduce or disappear.

When introducing a new kind of technology to students, some class time is lost in the process of students getting acquainted with it. Hence, the students and teacher should have at least one or two modules of training in using the new technology and full practice with the platform in order for them to know all the tools and materials that are available for them. This is because some participants mentioned the fact that when they were doing their online lessons, they had doubts and there was no one to answer or help them with those, which was a similar student response reported in Martín de Lama (2013). However, the platform had two different help forums: one for technical issues, and another for language and content questions. This 
forum could send instant notifications to the teacher whenever there was a question or doubted submitted, and it was presented to students at the beginning of the module. Nevertheless, most of them said that they forgot that it was available for them, or that they did not feel like asking something by that means.

In terms of the design of the blended lessons, as Tayşı and Başaran (2018) stated, it is important to design a blended learning course to keep students engaged and motivated during the process. Therefore, as mentioned in the design section, the course was designed using authentic and interactive material which the students found appealing and useful for their learning. Most of them also found the platform user-friendly, this mostly due to its interactive nature that allowed them to proceed through the lessons in an organized way, allowing them go back to any lesson whenever it was needed.

Another situation that was mentioned by the teacher and the students was the lack of opportunities to communicate in the online lessons, which is completely true. It is challenging in online lessons to create opportunities for oral communication. In the platform, there were some exercises where they had to record their voice describing or explaining something, but that is not language that occurs naturally since they were able to prepare it before recording it. Nonetheless, since they were having blended lessons, all the oral communication that could not happen in the online lessons, could happen in the face-to-face lessons.

On the one hand, traditional face-to-face lessons allow students to constantly participate and communicate with each other and with the teacher, as stated by Alonso, López, Manrique, and Viñes (2005). However, in this study's language program, the time in class is limited and instructors have a syllabus to follow which has to be completed in seventeen days; therefore, they often do not have the time to consider the different kinds of learning styles, or the different 
paces at which students learn. On the other hand, blended learning lessons did allow students to learn at their own pace and considered as many types of learning as possible. Nevertheless, online lessons did not give students the opportunity to communicate orally since they only had the chance of having written communication. This is an important issue in lessons that are $100 \%$ online. In terms of blended learning, this issue can be solved by focusing face-to-face lessons on communication; that is, lessons in the classroom should prioritize the practice of speaking, putting the grammar that was learned in the online lessons into use. This is an aspect that was not considered by the students in the interviews since they mainly focused on the idea of only online lessons, rather than the idea of blended lessons.

\section{Limitations and Implications for Future Research}

Several limitations were noted in this study as it developed. To begin, after analyzing the results, it can be observed that there was a small sample size; thus, additional research is needed with more groups in different contexts as well, e.g. other cities or countries. Furthermore, the difference in groups' size may have affected the calculation of the mean, since the comparison group had a bigger number of participants. This is an issue hard to comparison as a researcher because the number of students in each class also depends on the students that were willing to participate in the study, and on the students that kept registering or dropping the English course. In the case of the exams, there were sections that, for example, had five items, where each one valued $20 \%$. If a student made a mistake only in one of them, the difference would be $20 \%$ between scores, making data to be significantly different only because of one mistaken item. For future research, this is a matter that should be controlled by having each section to be more balanced in the number of test items. 
Since this was a comparison study, all the data collected were from one module only which might not have been enough for this kind of study due to the reason mentioned in the discussion part, which is that the students and the teacher needed more time to get familiarized with the platform and be able to use all the tools that it provided. Therefore, for future research, it might be better to have a longitudinal study with two parallel classes with a larger number of students, so the students who drop the class for any reason would not affect the sample significantly. Other variables should be also considered too, such as the number of absences and the number of times students used the help forum for their doubts.

Research with students involve different issues and situations that may occur and cannot be controlled by the researcher. Therefore, as VanDerLinden (2014) stated, there are a lot of roles to be considered and that should be part of the integration of a blended program into an English course. For example, the role of the students and their need of this kind of approach, the role of a teacher who is familiarized with web tools, the role of the institution who has to provide the paid online tools, any equipment needed by the teacher, and a constant available IT help for both the teacher and the students. As the author mentioned, blended learning is the result of everyone's collaborative work, and if there is no support or predisposition of one of them, it may considerably have a negative effect on the results of the experiment.

Concerning the blended learning lessons, the free version of the Canvas platform was used which has plenty of tools to design online lessons; nonetheless, since it is a free version, it has some limitations. Even though the lessons were already interactive, the premium version of Canvas has even more tools that can be used to improve them, such as the option of integrating other learning apps and tools within Canvas, more quizzes designs, different kinds of grade keepers instead of one, a more explicit calendar that shows the tasks for every day, and more. If a 
language institution decides to implement a blended learning approach in their English program, it is important for them to acquire the full version of an online learning platform so they can take advantage of all the tools that will help them design an appropriate blended learning program for their students. 


\section{References}

Alonso, F., Lopez, G., Manrique, D., \& Vies, J. (2005). An instructional model for web-based e-Learning education with a blended learning process approach. British Journal of Educational Technology, 36(2), 217-235. Retrieved from https://libwvu.on.worldcat.org/oclc/425023079

Ashby, W. (2015, June). Blended learning. Workshop presented at CBA Sucre, Bolivia Bañados, E. (2006). A blended-learning pedagogical model for teaching and learning EFL successfully through an online interactive multimedia environment. CALICO Journal, 23(3), 533-550. Retrieved from http://www.jstor.org/stable/24156354

Driscoll, M. (2002). Blended learning: Let's get beyond the hype. E-Learning, 1(4), 1-3.

Gill, D. (2009). Effective blended learning techniques. Journal of College Teaching \& Learning, 6(2), 1-14. Retrieved from https://doi.org/10.19030/tlc.v6i2.1167

Gleason, J. (2013). An interpretive argument for blended course design. Foreign Language Annals, 46(4), 588-609. doi:10.1111/flan.12050

Harrington, A. M. (2010). Problematizing the hybrid classroom for ESL/EFL students. TESLEJ: Teaching English As A Second Or Foreign Language, 14(3). Retrieved from http://www.tesl-ej.org/

Martín de Lama, M. T. (2013). A Spanish university case study: User's perception of blended methodology used for English Foreign Language learning. Journal Of English Studies, 11, 171-192. doi:10.18172/jes.2623

Oliver, M., \& Trigwell, K. (2005). Can "blended learning" be redeemed? E-Learning, 2(1), 1726. Retrieved from http://bit.ly/2Va819Y 
Rao, A. V. N. (2006). Effectiveness of blended learning. I-Manager's Journal of Educational Technology, 3(3), 30-36. Retrieved from https://search.proquest.com/docview/1473900405?accountid=2837

Sharma, P. (2010). Blended learning. ELT Journal, 64(4), 456-458. doi:10.1093/elt/ccq043

Tayşı, E., \& Başaran, S. (2018). An investigation into university EFL students and instructors' perceptions of using a learning management system. Journal Of Language And Linguistic Studies, 14(2), 100-112. Retrieved from http://jlls.org/index.php/jlls

VanDerLinden, K. (2014). Blended learning as transformational institutional learning. New Directions for Higher Education, 2014(165), 75-85. Retrieved from https://doi.org/10.1002/he.20085

Zhang, W. \& Zhu, C. (2018). Impact of blended learning on university students' achievement of English as a second language. International Journal on E-Learning. 17(2). 251-273. Retrieved from https://illiad.lib.wvu.edu/illiad.dll?Action=10\&Form=75\&Value=822675 


\section{Footnotes}

${ }^{1}$ The twelfth term was interrupted and therefore cancelled at the institution due to a political crisis in Bolivia which caused a national strike from October $20^{\text {th }}$ to November $15^{\text {th }}$. 


\section{APPENDIX A}

\section{Final Exams Units 3-4 (Pre-test)}

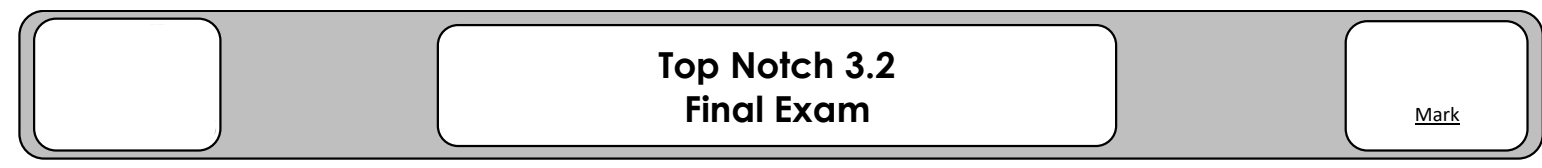

Student's Name:

Date:

Teacher's Name: Jamile S. Tango Rojas

\section{VOCABULARY.}

A. Match the sentences. Write the letter on the line.

1. It's easy and enjoyable to read

2. It's very poor quality

3. It's so interesting that you want to keep reading it.

a. It's a page-turner.

4. It's very popular and everyone is buying copies.

b. It's a best seller.

c. It's a fast read.

5. It's difficult to understand.

d. It's hard to follow.

e. It's trash.

B. What kind of service does each person want to have done? Use the words in the box.

$\begin{array}{ccc}\text { copying printing haircut } & \text { delivery } \\ & \text { shoe repair } & \text { dry-cleaning }\end{array}$

"I just bought this great Poster. Now I need to get it fixed so that I can hang it above my desk."

1.

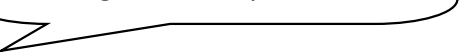
framing

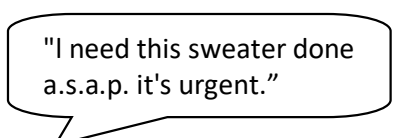

4.

5.

2.
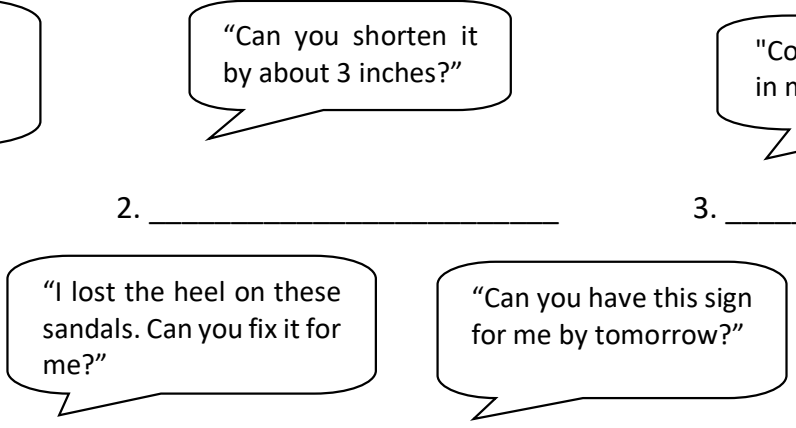

6.

\section{"Could I have these packages in my office by noon?"}

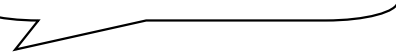

3.

"I have to get more handouts for tomorrow's meeting."

7.

GRAMMAR.

C. Read the services in Exercise B. Complete the sentences with the service each person needs. Use the passive causative.

1. He would like to get his poster framed

2. She wants to get

3. He'd like to have

4. She needs to have
5. She wants to have

6. He needs to get

7. He has to get 


\section{A. Choose the correct answer. Write the letter on the line.}

1. You can have someone ___ that for you.
a. do
b. does
c. to do that

2. The lawyer will make them the papers.

a. signed

b. sign

c. to sign

3. She got him her house before the party.
a. to clean
b. cleaned
c. clean

4. Why don't you get someone __ you?
a. helped
b. to help
c. help

5. Mrs. Oliver always makes people ___ whatever she wants.
a. to do b. did
c. do

6. Have someone else care of that?

a. taken b. to take c. take

\section{B. Complete each conversation with a logical response. Use so or not.}

1. A: Does this magazine cost less than this book?

B: I think

2. A: I'm glad the interview went well. Do you think they'll offer you a job?

B: I hope I I really like the company.
3. A: Is Scott going to meet us tonight?

B: Well, he's already an hour late, so I guess

\section{Respond to each question with a clause using that. Use the prompts.}

1. What do you think about the book you're reading? (hard to follow / I believe)

2. What is J.K. Rowling's most famous book? (Harry Potter / I suppose)

\section{Read. Choose the correct sentence in each pair. Write the letter on the line.}

1. a. I don't know if it's trash.

b. I don't know if is it trash.

2. a. Would you mind asking Angie whether I could see her book? her book?

b. Would you mind asking Angie that I could see

\section{LISTENING.}

E. Listen to the conversations. Then listen again and mark each statement True or False. (ActiveBook / More practice / Unit 3 / Listening Comprehension / Activity 1)

1. One of the women needs to get something replaced.

2. She also needs to have something drycleaned.

3. Her friend needs to get copies made.

\section{True False}

4. One of the women needs to get something framed.

5. One of the women needs to get something sent.

6. The first woman needs to have something shortened. her life?

b. Do you know why did Helen Keller write about

4. a. I wonder who is Anne's new friend.

b. I wonder who Anne's new friend is. 


\section{READING.}

A. Read the article. Answer true (T), false (F). i $\quad$ What's good to read?

if Any Reading is good for kids. If they like it, let them read it.

; At least that's what many experts are now saying. After a long time of believing that only certain types of reading materials were - appropriate, educators and child experts are changing their minds.

- They now say that any reading is good for developing and improving comprehension skills, and that children increase their $\mathbf{I}$ . vocabulary by reading, which also increases their comprehension.

I Some parents might be concerned that if left to choose their own books, their children would only choose easy material. They i I might think that children won't challenge themselves by reading above their level. But, in fact, the opposite is true. When children : i choose their own material, they generally pick book at a higher level than what a teacher would, if the topic of the reading is : . interesting to them.

I. Studies show that children who read for pleasure or for their own learning often do well in school subjects. Good readers often $\mathbf{i}$ I make better students. The only way to become a better reader is to practice.

I. So whether it's a teen romance novel, a music magazine, a comic book about superheroes, or an internet website, reading is i i good for the brain.

$\cdot-\cdot-\cdot \cdot-\cdot \cdot-\cdot-\cdot \cdot-\cdot-\cdot-\cdot \cdot-\cdot-\cdot-\cdot \cdot-\cdot-\cdot \cdot-\cdot-\cdot-\cdot-\cdot-\cdot \cdot-\cdot-\cdot-\cdot-\cdot \cdot-\cdot-\cdot$

1. All experts now believe that all reading is good for children, no matter who chooses their reading material.

2. Not many experts are changing their thinking about what children should be allowed to read.

3. Some experts believe that reading teen magazines and comic books can increase children's vocabularies.

4. One benefit is that children tend to choose books that are very easy to read.

5. One advantage of comic books and teen romances is that they help children become better readers.

\section{WRITING.}

B. Summarize the book you've read in no more than eight lines. 


\section{APPENDIX B \\ Post-Experiment Students' Interview \\ Interview 1}

Please comment on the use of technology both inside and outside the classroom regarding your experience during this module considering: Coursework, Canvas, projector, presentations' software, your mobile or computer device, online video or music, work in the library lab, online assignments, practice activities, communication with your instructor, discussion boards, messaging with classmates, etc.

1. In what ways have the online tools used in this course influenced your language learning? Follow up: Has it been distracting at all? Has it been more beneficial than the other classes that you have taken?

2. Have you noticed any difference in the materials used in this class compared to others? Follow up: Did they seem more authentic? Did they seem more challenging?

3. Do you think the use of online tools in this course provided you with extra opportunities for communicating in English?

Follow up: What is your opinion about having the opportunity of both required and voluntary communication and participation?

4. Do you think the use of online tools in this course enabled you to reflect on your own speaking and writing skills in English?

Follow up: If yes, in what ways? If not, why not?

5. Are there any tools, from the ones you used during this course, that you would use to take more control of your own language learning in the future?

6. Overall, are there any elements from the class that you found effective or helpful? 
Follow up: Are there any elements from the class that you found the least effective or helpful? 


\section{APPENDIX C \\ Post-Experiment Instructor's Interview}

\section{Interview 2}

Please comment on the use of technology both inside and outside the classroom regarding your experience with blended learning during the module: Coursework/Canvas, your mobile or computer device, work in the library lab, online assignments, practice activities, communication with students, etc.

1. Do you have an approach to integrating technology in your language teaching? Do you feel prepared to use technology in your courses?

2. Do you think that technology enhances your language teaching? Follow up question: If yes, what does it add? If not, why not?

3. Do you think there is an extra burden that technology places on your language teaching? Follow up question: If yes, to what extent does it complicate your teaching practice?

4. Do you usually incorporate authentic materials in your language instruction? Follow up question: Does technology play any role in it? How?

5. Do you think that technology is more appropriate for use at certain proficiency levels? Follow up question: Would you use this blended approach with a beginner level? Why or why not?

6. Are they any elements from this approach that you found effective or helpful? Follow up question: Are they any elements from this approach that you found the least effective or helpful? Which ones? 


\section{APPENDIX D \\ Post-Experiment Students' Interview Spanish Translation}

Comente sobre el uso de tecnología dentro y fuera del aula con respecto a su experiencia durante este módulo considerando: el trabajo de curso, Canvas, proyector, software de presentaciones, su dispositivo móvil o computadora, videos o música en línea, trabajo en el laboratorio de la biblioteca, tareas en línea, actividades de práctica, comunicación con su instructor, paneles de discusión, mensajes con compañeros de clase, etc.

1. ¿De qué manera las herramientas en línea que han sido utilizadas en este curso influyeron en su aprendizaje de idiomas?

Pregunta complementaria: ¿Han sido una distracción? ¿Han sido más beneficiosas que las clases presenciales que normalmente toma?

2. ¿Ha notado alguna diferencia en los materiales utilizados en esta clase en comparación con otros?

Pregunta complementaria: ¿Parecían ser más auténticos? ¿Parecían ser más desafiantes?

3. ¿Cree que el uso de herramientas en línea en este curso le brindaron más oportunidades para comunicarse en inglés?

Pregunta complementaria: ¿Cuál es su opinión sobre las oportunidades de comunicación y participación, tanto de manera solicitada como voluntaria?

4. ¿Cree que el uso de herramientas en línea en este curso le permitieron reflexionar sobre sus habilidades para hablar y escribir en inglés?

Pregunta complementaria: Si sí, ¿de qué manera? Si no, ¿por qué no? 
5. ¿Existen herramientas, de las que usó durante este curso, que usaría para tomar un mejor control de su aprendizaje de idiomas en el futuro?

6. En general, ¿hay algún elemento de la clase que le haya parecido efectivo o útil?

Pregunta complementaria: ¿Hay algún elemento de la clase que le haya resultado menos efectivo o útil? 